\title{
DIVERSIDADE METABÓLICA EM SOLO TRATADO COM BIOSSÓLIDOS
}

\section{ELIZABETH BARRETTO DE MENEZES LOPES}

Dissertação apresentada à Escola Superior de Agricultura "Luiz de Queiroz", Universidade de São Paulo, para obtenção do título de Mestre em Agronomia, Área de Concentração: Solos e Nutrição de Plantas.

PIRACICABA

Estado de São Paulo - Brasil

Novembro - 2001 


\title{
DIVERSIDADE METABÓLICA EM SOLO TRATADO COM BIOSSÓLIDOS
}

\author{
ELIZABETH BARRETTO DE MENEZES LOPES \\ Engenheiro Agrônomo
}

Orientador: Prof. Dr. Marcio Rodrigues Lambais

Dissertação apresentada à Escola

Superior de Agricultura "Luiz de Queiroz", Universidade de São Paulo, para obtenção do título de Mestre em Agronomia, Área de Concentração: Solos e Nutrição de Plantas.

PIRACICABA

Estado de São Paulo - Brasil

Novembro - 2001 
Dados Internacionais de Catalogação na Publicação (CIP) DIVISÃO DE BIBLIOTECA E DOCUMENTAÇÃO - ESALQ/USP

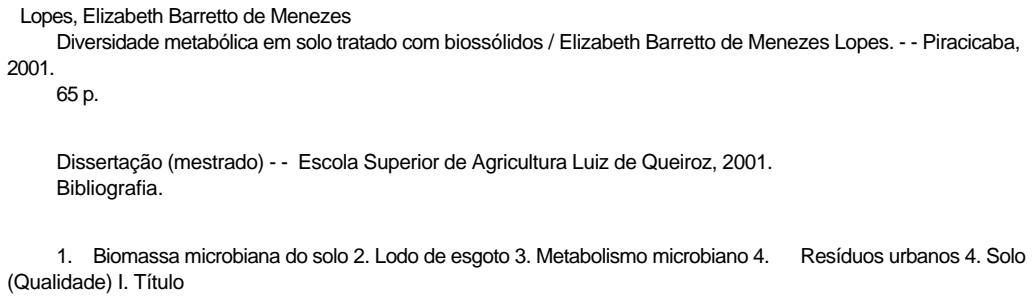

CDD 628.3

"Permitida a cópia total ou parcial deste documento, desde que citada a fonte - $\mathrm{O}$ autor" 


\section{DEDICATÓRIA}

À minha mãe, Maria Elizabete Barretto de Menezes Lopes, por proporcionar tudo isso, OFEREÇO

Aos meus filhos,

Pedro e Marcos,

Pela imensa compreensão e carinho

a mim reservados, 


\section{AGRADECIMENTOS}

À Fapesp, pela bolsa concedida e suporte financeiro para desenvolvimento da pesquisa;

À Escola Superior de Agricultura "Luiz de Queiroz", Universidade de São Paulo, em especial ao Departamento de Solos e Nutrição de Plantas, pela oportunidade oferecida para realização do Curso;

Ao Prof. Dr. Márcio Rodrigues Lambais, pela orientação, paciência, incentivo e confiança constantes;

Aos técnicos de laboratório, Denise Mescholotti e Fernando Baldessin, pela inestimável colaboração nas análises laboratoriais e, sobretudo, pela amizade;

À Prof. ${ }^{a}$ Elke Jurandir Bran Nogueira pela sempre amável disponibilidade;

À Prof ${ }^{\text {a }}$ Siu Mui Tsai pelas sugestões ;

Aos demais professores e funcionários do Departamento de Solos e Nutrição de Plantas pela agradável convivência e solicitude;

À bibliotecária Eliana Maria Garcia pela atenção e pronta correção das normas e referências bibliográficas;

Aos amigos do Laboratório de Microbiologia do Solo: Adriana, Adrianinha, Ângela, Beatriz, Denise, Eduardo, Janaína, Juliano, Simão, Robinson, Thaís e Yara, pela deliciosa convivência, trocas intelectuais e amizade;

Aos demais amigos de graduação e de mestrado que me acompanharam nesta trajetória; 
À Daniele Takahashi, pela amizade e preciosa colaboração nas análises estatísticas;

À Leandra Maria Scarpari, Luiz Fernando da Silva Martins e Marco Antônio Nogueira, por serem tão amigos e presentes;

A Cátia, Marcelo e Renata Bortoletto, pelo carinho e apoio constantes;

A Cristina, minha irmã;

Aos meus avós Barretto "in memorian" e Mafalda, por acreditarem sempre em $\operatorname{mim}$;

Ao César, pela paciência e bom humor;

Ao Antônio, pela infinita calma, estímulo e carinho. 


\section{SUMÁRIO}

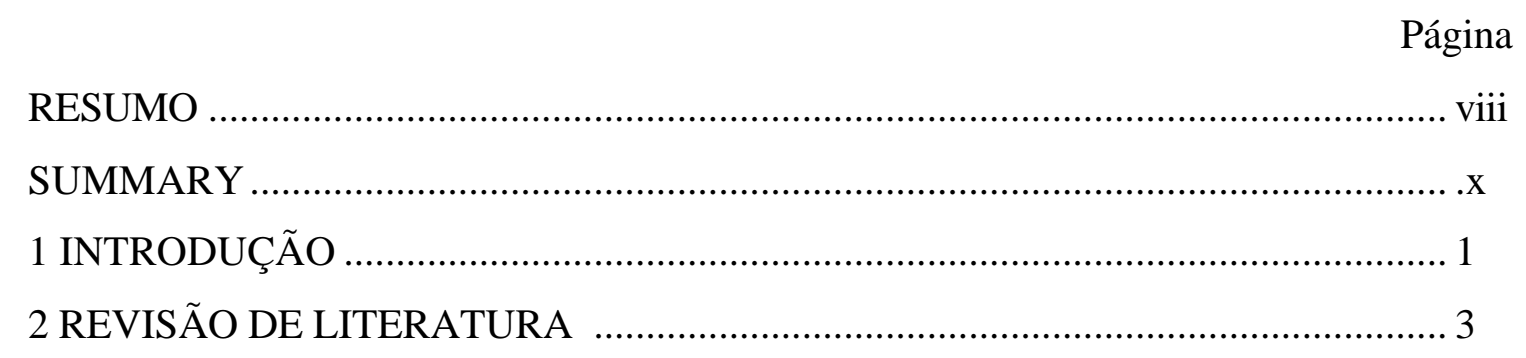

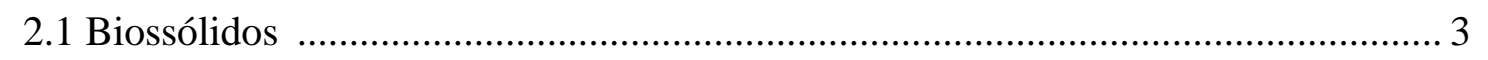

2.2 Qualidade do Solo ......................................................................................

2.3 Indicadores Microbiológicos.......................................................................... 7

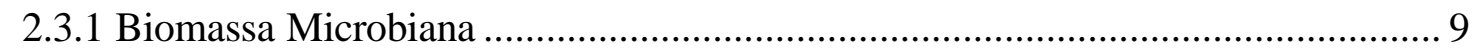

2.3.2 Respiração Basal e Respiração Induzida pelo Substrato …………………………. 10

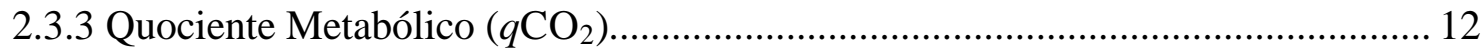

2.3.4 Diversidade Metabólica....................................................................................... 12

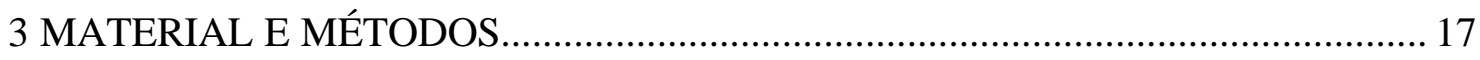

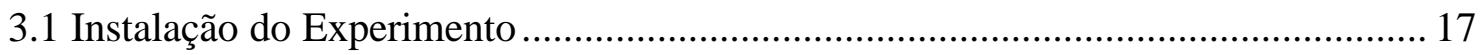

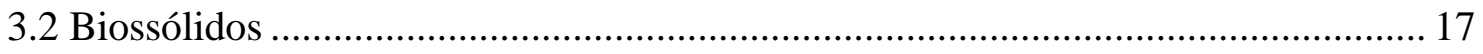

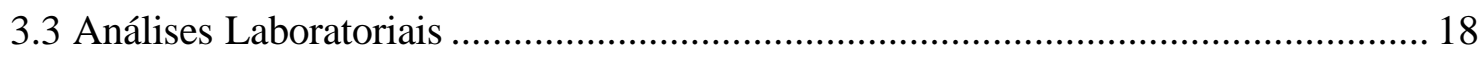

$3.3 .1 \mathrm{pH}$

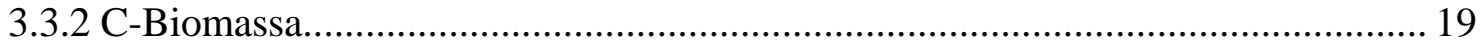

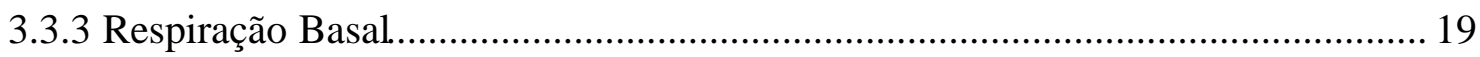

3.3.4 Respiração Induzida pelo Substrato................................................................ 20

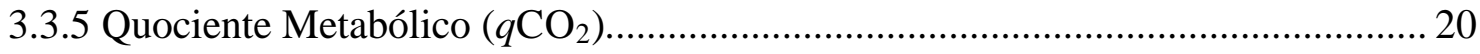

3.3.6 Diversidade Metabólica................................................................................... 21

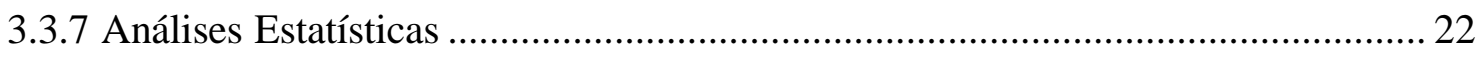

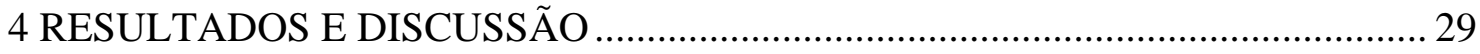




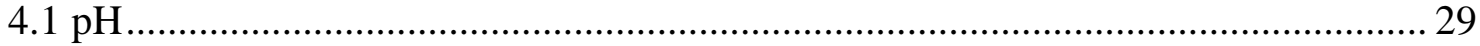

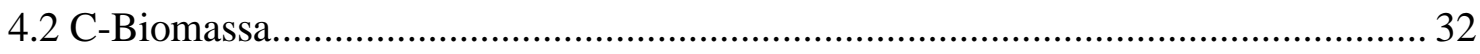

4.3 Respiração Basal e Respiração Induzida pelo Substrato ....................................... 35

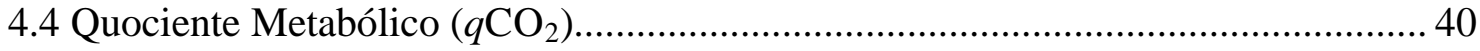

4.5 Diversidade Metabólica........................................................................................ 43

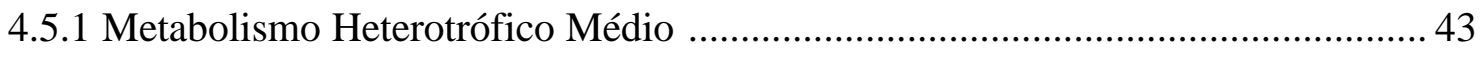

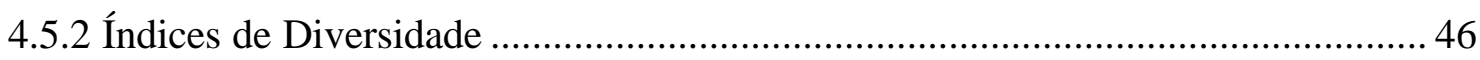

4.5.3 Perfis de Utilização de Substratos de C................................................................... 51

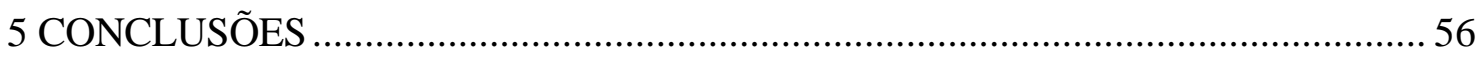

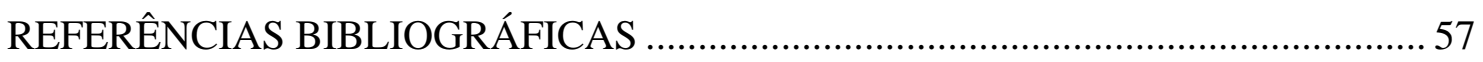




\section{DIVERSIDADE METABÓLICA EM SOLO TRATADO COM BIOSSÓLIDO}

Autora: Elizabeth Barretto de M. Lopes

Orientador: Prof. Dr. Marcio Rodrigues Lambais

\section{RESUMO}

A aplicação de biossólidos em solos agrícolas e/ou florestais é uma prática aceitável, tanto como forma de disposição destes materiais, quanto de melhorar as características físicas, químicas e biológicas do solo. No entanto, pouco se sabe dos impactos decorrentes desta utilização e dos seus efeitos sobre a estrutura das comunidades microbianas dos solos e sua capacidade metabólica. Assim, o objetivo deste trabalho foi determinar alterações quanti-qualitativas na diversidade metabólica dos microrganismos do solo após a adição de biossólidos e identificar possíveis indicadores de alteração de qualidade do solo. $\mathrm{O}$ delineamento experimental constituiuse de 4 doses de biossólidos da ETE-Franca, equivalentes à 6, 12, 24 e $48 \mathrm{Mg} \mathrm{ha}^{-1}$, mantendo-se um controle sem adição de biossólido. Foram utilizadas 4 repetições por tratamento, compreendendo 20 sub-parcelas. Estas sub-parcelas foram incubadas por 1, 2, 4, 8 e 16 semanas, perfazendo um total de 120 parcelas. Após o período de incubação, amostras de solo foram coletadas para as determinações de pH, C-biomassa, Respiração Basal (RB), Respiração Induzida pelo Substrato (RIS), Quociente Metabólico ( $q \mathrm{CO} 2)$ e Diversidade Metabólica. Houve um aumento transiente do $\mathrm{pH}$ nos tratamentos com as maiores doses de biossólido, em relação ao controle. Após 16 semanas de incubação os solos com biossólidos apresentaram $\mathrm{pH}$ mais baixo do que o controle sem biossólido. $\mathrm{O}$ 
C-biomassa apresentou comportamento semelhante, com os valores decrescendo e tendendo a estabilização, em relação ao controle sem biossólido. A atividade metabólica com base na RB, RIS e MHM indicou uma indução transiente no metabolismo da microbiota do solo nos tratamentos com as maiores doses de biossólido, tanto no início quanto no final do período de incubação. Os maiores valores de $q \mathrm{CO}_{2}$ nos solos com as maiores quantidades de biossólidos sugerem a ocorrência de condições estressantes para a microbiota e sucessão de populações microbianas. A utilização de substratos de $\mathrm{C}$ pela comunidade microbiana foi substancialmente influenciada pela quantidade de biossólido adicionado ao solo e pelo período de incubação. Os maiores valores de Riqueza de Substratos (S) e Diversidade Metabólica $(\mathrm{H})$ observados nos tratamentos que receberam as maiores quantidades de biossólido, no início do período de incubação, são indicativos de um estímulo da microbiota nativa e da contribuição de novas células microbianas decorrentes da adição do biossólido. As similaridades entre os perfis de utilização de substratos C diminuíram com o aumento da concentração de biossólido no solo, em relação ao controle sem biossólido, e aumentaram em função do período de incubação, sugerindo uma indução transiente na diversidade metabólica do solo em função da aplicação de biossólido da ETE-Franca. Solos que receberam altas doses de biossólidos apresentaram atividades metabólicas não observadas no solo sem biossólidos, no início do período de incubação, e perderam algumas atividades no final do período de incubação, em relação ao controle sem biossólido. No geral, os resultados sugerem que a aplicação de biossólidos da ETE-Franca no solo argiloso utilizado provoca um distúrbio na fisiologia da microbiota do solo e que aplicações sucessivas de altas doses de biossólido podem ocasionar alterações significativas na capacidade metabólica dos solos. 


\title{
METABOLIC DIVERSITY IN A SOIL AMENDED WITH BIOSOLIDS
}

\author{
Author: Elizabeth Barretto de M. Lopes \\ Adviser: Prof. Dr. Marcio Rodrigues Lambais
}

\section{SUMMARY}

The use of biosolids in agricultural and/or forestry soils has been an acceptable practice to dispose as well as to improve physical, chemical and biological soil properties. However, the impacts of biosolids application on microbial community structures and metabolic diversity in agricultural soils are relatively unknown. The aim of this work was to determine quantitative and qualitative alterations in the metabolic diversity of a clay soil upon treatment with biosolids. A clay soil was amended with the equivalent to $6,12,24$ and $48 \mathrm{Mg} \mathrm{ha}^{-1}$ of biosolids from the City of Franca (SP) Sewage Treatment Plant. A control without biosolids was also used. Four repetitions per treatment were used, totalizing 20 sub-parcels. Sub-parcels were incubated for 1, 2, 4, 8 and 16 weeks, after incorporating the biosolids, totaling 120 microcosms. After the incubation period, soil samples were collected to determine $\mathrm{pH}$, Basal Respiration (BR), Substrate Induced Respiration (SIR), C-biomass, Metabolic Quotient $\left(q \mathrm{CO}_{2}\right)$ and Metabolic Diversity. A transient increase in soil $\mathrm{pH}$ was observed in the treatments with the higher concentrations of biosolids, compared to the control without biosolids. After 
16 weeks of incubation, the $\mathrm{pH}$ of soils with biosolids was lower than in the control without biosolids. The C-biomass also showed a transient increase in soils with biosolids at early time points, and did not statistically differ from the control at late time points. Transient increases in metabolic activities, based on BR, SIR and AWCD (Average Well Color Development), were observed in soils with the higher concentrations of biosolids at early time points. Higher values of $q \mathrm{CO}_{2}$ in soils with higher concentrations of biosolids at the earliest and latest time points suggests stressing conditions to the microbial community and alterations in microbial community structure. The utilization of C-substrates by the soil microbial community was greatly affected by the concentration of biosolids added and by the incubation time. Higher values of Substrate Richness (S) and Metabolic Diversity $(\mathrm{H})$ in the soils with the higher concentrations of biosolids at early time points indicate that biosolids stimulate the activity of soil microorganisms and contribute with new activities. The similarities between the Csources utilization profiles in the soil amended with biosolids and the control were lower in soils with the higher concentrations of biosolids. The similarities of C-source utilization profiles in the soils with biosolids and the control increased during the incubation time. Soils amended with the higher concentrations of biosolids showed metabolic activities not observed in the control soil at the early time points. The ability to use several $\mathrm{C}$-sources was lost at the latest time point. In general, the results suggest that the incorporation of biosolids to the clay soil disturbs soil microbial physiology and that the successive application of biosolids to the soil may significantly alter the soil metabolic activities. 


\section{INTRODUÇÃO}

O potencial de utilização de biossólidos de Estações de Tratamento de Esgotos (ETEs) em solos agrícolas e/ou florestais vem aumentando consideravelmente nos últimos tempos, tanto como uma forma de disposição destes materiais, como uma maneira de se reciclar uma importante fonte de nutrientes, principalmente $\mathrm{N}$ e $\mathrm{P}$. No entanto, este material pode conter metais pesados passíveis de ocasionar a poluição do solo. Alguns metais, apesar de micronutrientes essenciais para plantas e microrganismos, podem ser tóxicos em altas concentrações.

Efeitos adversos de metais pesados nos microrganismos do solo podem alterar a qualidade do solo, principalmente no que se refere a ciclagem de nutrientes.

Estudos recentes, geralmente realizados em outros países, reportam sobre os efeitos da aplicação de bissólidos nas atividades microbianas básicas, principalmente sobre a mineralização do $\mathrm{C}$ e N. Os resultados gerados são, normalmente, contraditórios ou até mesmo discrepantes, provavelmente devido à alta redundância destas atividades enzimáticas no solo.

A contaminação do solo por metais ocasiona uma alteração na comunidade microbiana, selecionando organismos tolerantes. Algumas espécies podem ser eliminadas, enquanto outras aumentam em abundância. Esta substituição de espécies nem sempre reflete alterações nas atividades bioquímicas ou biomassa microbiana do solo, por exemplo.

Assim, torna-se necessário estabelecer indicadores confiáveis que sejam sensíveis a estresses ambientais. Os indicadores microbiológicos regulam os processos ecológicos do solo e refletem as condições de manejo atuais. Desta maneira, são úteis 
para determinação dos efeitos positivos e negativos sobre a qualidade do solo e a sustentabilidade das práticas agrícolas.

O impacto da aplicação de biossólidos em solos agrícolas pode ser melhor compreendido, também, através da determinação de alterações na diversidade metabólica dos microrganismos. Dados sobre alterações da diversidade metabólica dos microrganismos dos solos brasileiros são inexistentes, mas, aliados a outros parâmetros, podem ser úteis para avaliar o impacto causado pela utilização agrícola de biossólidos de ETEs. Tanto análises de tamanho e atividade, quanto de estrutura das comunidades microbianas, podem trazer grande contribuição para a geração de índices de qualidade biológica de solos, que podem ser utilizados para o monitoramento da aplicação agrícola de biossólidos.

Desta maneira, o objetivo deste trabalho é determinar o impacto de aplicação de biossólidos da ETE-Franca nas atividades e diversidade metabólica de um solo argiloso. 


\section{REVISÃO DE LITERATURA}

\subsection{Biossólidos}

A WEF (Water Environment Federation - 1993), sugere o termo "biossólido" para designar o lodo produzido pelos sistemas de tratamento biológicos de esgotos, desde que seu destino final tenha uma finalidade útil. O termo biossólido é reservado para um produto estabilizado, caso contrário são empregados os termos torta, lodo ou sólidos. Trata-se de um material heterogêneo, cuja composição depende do tipo de tratamento utilizado para tratar o esgoto e das características das fontes geradoras, ou seja, origem doméstica ou industrial.

A Região Metropolitana de São Paulo (RMSP), com uma população estimada de 17 milhões de habitantes, tem seus esgotos tratados por cinco grandes estações de tratamento: Barueri, Suzano, Parque Novo Mundo, São Miguel e ABC. Atualmente, o conjunto das estações tratam cerca de $15 \mathrm{~m}^{3} \mathrm{~s}^{-1}$ de esgotos e com previsão para tratarem $50 \mathrm{~m}^{3} \mathrm{~s}^{-1}$, no ano 2015 (Companhia de Saneamento Básico do Estado de São Paulo - SABESP, 2001).

A produção atual de lodo é de 235 toneladas por dia e para o ano 2015 a previsão é de 750 toneladas diárias, em base seca. Assim, a Companhia de Saneamento Básico do Estado de São Paulo (SABESP), desenvolveu um Plano Diretor de Uso e Disposição de Lodos da RMSP, no qual foram contempladas várias alternativas para disposição final de lodos, com destaque para aterro exclusivo, uso agrícola e incineração (SABESP, 2001).

Os principais resultados obtidos deste Plano Diretor foram:

- Elaboração de um Manual para utilização do biossólido da ETE-Franca; 
- Elaboração de uma norma para utilização agrícola de biossólidos (Companhia de Tecnologia e Sanemento Ambiental - CETESB, 1998).

- Registro do biossólido gerado na ETE-Franca, pelo Ministério da Agricultura e do Abastecimento, como Condicionador de Solo, com o nome de SABESFÉRTIL.

Com a aplicação do biossólido na agricultura, a SABESP deixará de investir em aterros sanitários, para a disposição final de biossólidos, aproximadamente $\mathrm{R} \$ 450.000 .000,00$ na $\mathrm{RMSP}, \mathrm{R} \$ 20.000 .000,00$ no Interior do Estado de São Paulo e R\$ 10.000.000,00 no Litoral do Estado de São Paulo. O volume de lodo de esgoto produzido na RMSP corresponde a 93\% do total produzido no estado, sendo que o interior e o litoral contribuem com 5 e $2 \%$, respectivamente.

A reciclagem agrícola de biossólidos de origem doméstica é uma tecnologia aceitável, tanto como disposição de resíduos como de enriquecimento do solo. A aplicação de biossólidos no solo geralmente promove um aumento na fertilidade, devido à mineralização da matéria orgânica, estimula a atividade microbiana e ainda ocasiona uma melhoria nas características físicas ao reduzir a densidade, aumentar a porosidade e estabilizar os agregados. Além disso, o incremento de carbono orgânico no solo resulta no aumento da capacidade de retenção de água (Stamatiadis et al., 1999).

Por outro lado, este processo exige a definiçãa de critérios seguros para sua implementação, principalmente no que se refere à lixiviação de nitrato (Buchanam \& Glissman, 1991) e a mobilidade dos metais pesados. Metais pesados contidos nos biossólidos podem alcançar níveis tóxicos no solo e ser transferidos para a cadeia trófica. No solo, reações de adsorção, complexação, oxidação-redução e precipitação controlam a disponibilidade e solubilidade dos metais. A disponibilidade destes elementos, na forma catiônica, depende do $\mathrm{pH}$ do solo. Os biossólidos são uma das maiores fontes de metais em solos agrícolas. Apesar de essenciais para as atividades microbianas, em concentrações excessivas podem causar toxicidade, inibindo atividades enzimáticas essenciais, e alterar a estrutura das comunidade microbianas. (Leita et al., 1995 \& Torsvik et al., 1998). 
Embora o Manual de Utilização do Biossólido da ETE-Franca e a Norma P.4.230da CETESB (São Paulo, 1999), contemplem um controle rigoroso da qualidade e quantidade dos biossólidos a serem aplicados, em função das características físicas e químicas do solo receptor, e um monitoramento das variações dessas características, ainda não existe uma maneira segura de monitorar as alterações na qualidade biológica do solo que por ventura possam ocorrer. A utilização de altas doses de biossólidos pode aumentar o potencial de impacto ambiental, devido à presença de espécies químicas tóxicas, implicando em modificações na diversidade biológica do solo e alterações de sua funcionalidade. A diminuição da diversidade microbiana no solo pode, em última análise, resultar em diminuição da ciclagem de nutrientes e crescimento de plantas, muito embora a maioria das atividades microbianas apresentem alto grau de redundância.

\subsection{Qualidade do Solo}

A Soil Science Society of America (1997) define qualidade do solo como: " a capacidade de uma classe específica de solo para funcionar dentro dos limites de um ecossistema natural ou manejado, sustentando a produtividade biológica, mantendo a qualidade ambiental e promovendo a saúde animal e vegetal”.

Outras organizações têm sugerido ainda que a sustentabilidade da agricultura deveria envolver o manejo bem sucedido de recursos que satisfaçam as necessidades humanas, enquanto mantêem ou estimulam a qualidade do ambiente e a conservação dos recursos naturais (Consultative Group on International Agricultural Research, 1898).

Apesar desta relevância, a qualidade do solo ainda não foi adotada como um indicador de sustentabilidade do sistema de manejo agrícola. Em uma recente revisão sobre a contribuição da qualidade do solo para a saúde ambiental, Jaenicke (1998) concluiu que a qualidade do solo continua a receber pouca atenção, embora haja uma maior conscientização dos potenciais benefícios de uma definição de indicadores de 
qualidade. Salienta também, que existem brechas significativas em nossa habilidade para identificar as relações físicas, químicas e ecológicas necessárias à qualidade ambiental.

A identificação destas relações torna-se difícil devido a, pelo menos, 5 limitações (Jaenicke, 1998):

1 - Relações causais entre qualidade do solo e funções do ecossistema, incluindo conservação da biodiversidade, produção da biomassa e conservação do solo e água, são dificilmente definidas ou quantificadas. A verdadeira calibração da qualidade do solo requer mais do que uma mera comparação de valores entre os diferentes sistemas de manejo.

2 - Embora sejam muitos os indicadores que refletem a capacidade atual do solo para funcionar, são poucos que podem predizer respostas do solo a distúrbios.

3 - Os sistemas de manejo da terra são, freqüentemente, demasiadamente complexos, e assim, inacessíveis para o monitoramento da qualidade do solo.

4 - Mensurações da qualidade do solo são geralmente apresentadas como uma única ferramenta. No entanto, para serem efetivas, necessitam ser integradas a indicadores biofísicos e sócio-econômicos.

5 - Muitas avaliações são pontuais, entretanto, ecossistemas são manejados de forma geral, no nível de paisagem.

As relações entre as muitas funções do ecossistema, como por exemplo a conservação da biodiversidade, tem sido ignoradas como indicadores da sustentabilidade do manejo da terra (Herrick, 2000). Da mesma forma, embora a comunidade ambiental geralmente aceite que a qualidade da água depende da qualidade do solo, há pouca consciência da função que o solo exerce na diversidade e resiliência das comunidades de plantas e animais (Hillel, 1991).

$\mathrm{O}$ acesso a pesquisas tradicionais para calibração de indicadores ambientais não envolve, necessariamente, experimentos dispendiosos. Estes devem, entretanto, ser capazes de estabelecer as relações causais entre os indicadores de qualidade do solo e as funções do ecossistema na conservação do recurso solo e água (Herrick, 2000). 


\subsection{Indicadores Microbiológicos}

O funcionamento do ecossistema solo é largamente governado pela dinâmica da microbiota. O componente biológico é responsável pela formação do húmus, ciclagem de nutrientes, estrutura física e por muitas outras funções (Lynch \& Bragg, 1985). A microbiota tem uma função essencial na decomposição da matéria orgânica. Reduções na sua diversidade ou abundância podem afetar a ciclagem de nutrientes (Giller et al., 1998).

Os microrganismos são bem mais importantes para o equilíbrio biológico dos ecossistemas, quando comparados com mamíferos ou aves, já que foram preponderantes para o surgimento das plantas na Terra e, portanto, dos animais (Hawksworth, 1992). Waksman (1927), investigando microrganismos e parâmetros físicos e químicos do solo, concluiu que os parâmetros biológicos deveriam ser utilizados para avaliar a fertilidade do solo. Os parâmetros utilizados, então, foram: o número de microrganismos, nitrificação, liberação de $\mathrm{CO}_{2}$, decomposição da celulose, fixação biológica do nitrogênio, atividade catabólica e potencial de oxidação-redução.

No entanto, os processos de mineralização do C e N-orgânico apresentam alto grau de redundância, isto é, diferentes populações de microrganismos podem, em diferentes condições ambientais, realizar esses processos. Assim a diminuição da atividade de uma população de microrganismos por alteração das condições ambientais poderá ser compensada pelo aumento da atividade de outra população, sem alteração significativa da atividade total da comunidade. Atividades apresentando alto grau de redundância dificilmente se correlacionam com alterações da qualidade do solo, embora esses parâmetros sejam úteis na determinação das taxas de degradação de materiais orgânicos no solo, como biossólidos.

Critérios básicos para utilização das propriedades microbianas no monitoramento da qualidade do solo têm sido propostos (Brookes, 1995):

1 - Essas propriedades devem ser exatas e precisamente avaliadas para se obter êxito em uma ampla escala de tipos e condições de solo; 
2 - Devido ao alto número de amostras analisadas normalmente, as propriedades microbianas devem ser fácil e economicamente avaliadas;

3 - As propriedades microbianas devem ser sensíveis a estresses, mas também suficientemente estáveis para não fornecer alarmes falsos;

4 - Devem ter validação científica, com base na realidade e conhecimento atual;

5 - Duas ou mais propriedades, independentes, devem ser utlizadas. Nesse caso, suas interrelações no ambiente devem ser conhecidas.

Os efeitos de altas e baixas concentrações de metais pesados para microrganismos e processos microbianos, tanto em ensaios de laboratório quanto de campo, podem ser discrepantes. Assim, altas concentrações de metal podem não ser passíveis de ocasionar efeitos deletérios sobre as atividades microbianas e, inversamente, baixas concentrações podem produzir efeitos negativos (Baath, 1989).

Estes dados contraditórios podem ser devidos tanto à alteração da biodisponibilidade dos metais (devido ao $\mathrm{pH}$, conteúdo de matéria orgânica ou conteúdo de argila, por exemplo), como a diferenças na sensibilidade dos microrganismos ou processos microbianos aos metais.

Stenberg (1999) enfatiza que nenhum indicador individualmente conseguirá descrever e quantificar todos os aspectos da qualidade do solo. Nem mesmo uma única função do solo pode ser avaliada, já que deve haver uma relação entre todos os atributos do solo. Assim, um número mínimo de indicadores deve ser selecionado. Os critérios para a seleção de indicadores relacionam-se, principalmente, com a sua utilidade em definir os processos do ecossistema. Estes integram as propriedades físicas, químicas e biológicas, além da sensibilidade ao manejo e variações climáticas (Doran, 1997).

Entretanto, Stamatiadis et al. (1999) avaliando modificações na qualidade de solos contaminados com biossólidos observaram que apenas a matéria orgânica e os parâmetros microbiológicos apresentaram padrões alterados, sendo que os indicadores físico-químicos permaneceram inalterados.

Assim, indicadores microbiológicos sensíveis a variações ambientais, como a Biomassa Microbiana, Respiração Basal, Respiração Induzida pelo Substrato e 
Quociente Metabólico foram selecionados para avaliar o efeito de biossólidos em solo argiloso.

\subsubsection{Biomassa Microbiana}

Um dos parâmetros microbiológicos mais utilizados em estudos de impactos ambientais sobre a microbiota dos solos é a quantidade de biomassa. A biomassa microbiana é um dos componentes que controlam funções chaves no solo, como a decomposição e o acúmulo de matéria orgânica, ou transformações envolvendo os nutrinetes minerais. Representa, ainda, uma reserva considerável de nutrientes, os quais são continuamente assimilados durante os ciclos de crescimento dos diferentes organismos que compõem o ecossistema. Conseqüentemente, solos que mantêm um alto conteúdo de biomassa microbiana são capazes não somente de estocar, mas também de ciclar mais nutrientes no sistema (Stenberg, 1999).

Isoladamente, a biomassa microbiana pouco reflete as alterações da qualidade do solo, apesar de ser um indicador precoce de intervenções antrópicas (Brookes, 1995). Diferentes práticas de manejo podem favorecer o acúmulo ou o decréscimo de biomassa microbiana (Chander \& Brookes, 1991; Chander et al., 1995). Em geral, a adição de resíduos orgânicos ao solo induz um aumento transiente da biomassa, medida pela quantidade de $\mathrm{C}$ ou $\mathrm{N}$ nas células microbianas. Por outro lado, a matéria orgânica pode mascarar um possível efeito deletério de espécies químicas tóxicas presentes em biossólidos sobre a microbiota. O maior estímulo do crescimento das populações microbianas na presença de matéria orgânica, em relação ao efeito inibitório de metais pode ser freqüentemente observado em solos que receberam biossólidos.

Decréscimos significativos no C-biomassa foram observados em solos tratados com biossólidos com altas taxas de metais, sugerindo uma menor eficiência de síntese, quando comparados com solos que receberam a adição de menores taxas de metais. Por outro lado, maiores concentrações de matéria orgânica contidas no 
biossólido incrementaram a capacidade de crescimento microbiano e a imobilização de metais (Khan \& Scullion, 1999).

Decréscimos na biomassa microbiana também foram observados por Khan \& Scullion (2000). Neste caso, o C-biomassa apresentou correlação negativa com a concentração de metais no solo. No entanto, essa correlação não foi observada em solos argilosos, sugerindo que a disponibilidade de metais pode ser menor em solos com maior teor de colóides.

Resultados semelhantes foram observados por Chander \& Brookes (1991) e Baath et al. (1998), que reportaram uma redução no carbono da biomassa microbiana em solos contaminados com biossólidos ricos em $\mathrm{Cu}$, não se observando efeitos para Ni e Zn.

\subsubsection{Respiração Basal e Respiração Induzida pelo Substrato}

A Respiração Basal (RB) reflete a atividade da microbiota do solo responsável pela degradação de compostos orgânicos, enquanto a Respiração Induzida pelo Substrato (RIS) reflete o potencial de microrganismos zimógenos, os quais apresentam aumentos de atividade degradatória em resposta à adição de $\mathrm{MO}$ ao solo (Anderson \& Domsch, 1978). Esta medida é particularmente útil para avaliar a respiração em solos estressados e/ou perturbados, já que solos estressados tendem a responder mais lentamente à adição desta fonte de carbono, em relação a solos não perturbados (Wardle, 1994).

A influência de metais na respiração do solo é pouco clara. Diminuições significativas na liberação de $\mathrm{CO}_{2}$ em solos contaminados com metais têm sido encontradas (Doelman \& Haanstra, 1984; Hattori, 1989). Da mesma forma, aumentos da liberação de $\mathrm{CO}_{2}$ em solos contaminados com metais têm sido relatados (Leita et al., 1995; Fließbach et al., 1994 e Bardgett \& Saggar, 1994). Tem sido proposto que a respiração em resposta a adição de metais pode variar com o período de incubação do biossólido no solo e com a taxa de aplicação (Doelman \& Haanstra, 1984; Khan \& Scullion 2000). 
Em um estudo sobre solos contaminados com metais pesados a liberação de $\mathrm{C}-\mathrm{CO}_{2}$, em relação à quantidade de C-biomassa, aumentou consideravelmente nos solos que receberam as maiores quantidades de metais, sugerindo que os microrganismos do solo dispendem mais energia em condições de estresse (Leita et al. 1995).

Da mesma forma, em avaliações de alterações da qualidade de solos resultantes da injeção de biossólidos na forma líquida, observou-se que a respiração do solo foi 4 vezes maior no solo contaminado, em relação ao solo controle. Esta variável foi altamente indicativa da atividade microbiana, apresentando alta correlação com outros parâmetros microbiológicos, como o C-biomassa e taxas de mineralização e nitrificação (Stamatiadis et al. 1999).

Efeitos de estímulo na respiração basal e induzida, com o incremento da quantidade de biossólido aplicada, também foram observados por Emmerling et al. (2000). Estes autores sugerem que a adição de substâncias orgânicas e nutrientes, provavelmente devido a um incremento no $\mathrm{pH}$ do solo, seja responsável por esta resposta. $\mathrm{O}$ conteúdo de matéria orgânica influenciaria a respiração microbiana devido, também, a um incremento na capacidade de retenção de água. No entanto, deve-se ressaltar que o biossólido apresentava baixas concentrações de metais.

As taxas de respiração microbiana em solos contaminados com metais podem variar com o período de incubação. Aumentos significativos nas taxas de respiração têm sido observados após a adição de metais, mas decrescem algumas semanas depois (Khan \& Scullion, 2000). No geral, as respostas são mais pronunciadas em solos onde a disponibilidade de metais é maior devido, provavelmente, a alterações na estrutura da comunidade microbiana. Entre 3 e 7 semanas após a adição do biossólido, houve um aparente incremento na proporção de fungos na biomassa microbiana, particularmente em solos com altas taxas de metais. Assim, a respiração total do solo poderia ter sido determinada pela comunidade bacteriana, no início da incubação e, posteriormente, pela comunidade fúngica (Khan \& Scullion, 2000). 


\subsubsection{Quociente Metabólico $\left(q \mathrm{CO}_{2}\right)$}

Uma alta taxa de respiração pode indicar tanto um distúrbio ecológico (incorporação de resíduos orgânicos, por exemplo), como um alto nível de produtividade do ecossistema (Islam \& Weil, 2000). Uma variável de interpretação mais fácil é a taxa de respiração por unidade de biomassa microbiana, ou quociente metabólico $\left(q \mathrm{CO}_{2}\right)$.

$\mathrm{O} q \mathrm{CO}_{2}$ tem sido utilizado como um indicador de estresse microbiano e interpretado como "eficiência microbiana", já que se trata de uma medida da energia necessária para manutenção da atividade metabólica em relação à energia necessária para síntese de biomassa ( Bardgett \& Saggar, 1994).

Resultados de estudos dos efeitos de metais no $q \mathrm{CO}_{2}$ têm sido variados. Leita et al. (1995) e Bardgett \& Saggar (1994) encontraram uma relação positiva entre concentração de metal no solo e $q \mathrm{CO}_{2}$. Da mesma forma, Khan \& Scullion (1999) encontraram incrementos no $q \mathrm{CO}_{2}$ em solos contaminados com altas concentrações de metais.

Valores de $q \mathrm{CO}_{2}$ significativamente maiores em solos poluídos, quando comparados com solos não contaminados, também foram encontrados por Brookes \& Mc Grath (1984).

Por outro lado, Khan \& Scullion (2000), avaliando alterações microbianas em decorrência de contaminações por metais, sugerem que a utilização desse índice como indicativo de estresses ou distúrbios é limitada, atribuindo alguns resultados discrepantes a alterações na estrutura da comunidade microbiana, como um incremento na proporção de fungos na comunidade microbiana dos solos, por exemplo.

\subsection{Diversidade Metabólica}

Estudos têm demonstrado que a contaminação do solo por metais pode ocasionar uma alteração na comunidade microbiana, normalmente com seleção de microrganismos tolerantes (Giller et al., 1998). Algumas espécies podem ser eliminadas, enquanto outras aumentam em abundância devido à menor competição por substratos, $\mathrm{o}$ que pode resultar em alterações dos índices de diversidade microbiológica (van Beelen 
\& Doelman, 1997). Diversidade biológica é a variedade de espécies no ecossistema, bem como a variabilidade genética entre indivíduos da mesma espécie (Conservation Foundation, 1987). Biodiversidade pode também ser definida como uma abundância da vida, indicada pela variedade da biota, e inter-parentesco de processos bioquímicos no solo (Kennedy \& Smith, 1995).

A diversidade da microbiota do solo é extremamente elevada. Só entre os fungos existem mais espécies do que todas as espécies animais e vegetais conhecidas atualmente. Através da análise da cinética de reassociação de DNA, tem sido estimado que o solo pode conter mais de 10.000 genomas (Torsvik et al., 1998). Os perigos da redução da diversidade microbiana, em decorrência de vários fatores, especialmente das atividades antrópicas, têm sido objeto de preocupação. Sabe-se que a manutenção da biodiversidade é considerada, nos dias de hoje, extremamente importante, e essa preocupação não envolve apenas a área de ciências biológicas mas também a economia, a religião e a ética, entre outras. São cada vez mais reconhecidos os perigos da diminuição da biodiversidade: desequilíbrios ecológicos de conseqüências imprevisíveis e a extinção de espécies, cujas propriedades e características poderiam ser de interesse não apenas para a manutenção desse equilíbrio, mas para o próprio bem-estar da humanidade (Mello \& Azevedo, 1998).

O estudo da diversidade biológica dos solos é necessário para:

1) aumentar nosso conhecimento dos recursos genéticos disponíveis e entendimento da distribuiç̧ão da diversidade sobre a Terra;

2) aumentar nosso conhecimento do papel funcional da diversidade e;

3) identificar alterações na diversidade associadas com distúrbios ou técnicas de manejo específicas (Kennedy \& Smith, 1995).

A diversidade funcional de comunidades microbianas do solo inclui a variedade e a expressão relativa de cada atividade individual envolvida nas funções de decomposição, de transformações de nutrientes, de promoção e supressão do crescimento das plantas dentre outros (Giller et al., 1997). A diversidade de funções de decomposição, ou seja, de utilização de substratos orgânicos por populações heterotróficas, representa somente uma parcela da diversidade funcional das 
comunidades microbianas dos solos. A diversidade metabólica da microbiota do solo está relacionada com a capacidade dos microrganismos participarem de processos chaves como a ciclagem de $\mathrm{C}$ e $\mathrm{N}$, decomposição de moléculas orgânicas complexas e/ou raras e outras transformações (Zak et al., 1994).

As análises de diversidade metabólica são feitas com base na variação (igualdade) dos perfis de resposta catabólica, a partir do estudo do padrão de utilização de diferentes substratos de C (Garland \& Mills, 1991; Zak et al., 1994; Garland, 1996; Degens \& Harrris, 1997). Uma das formas pioneiras desse tipo de estudo envolve a

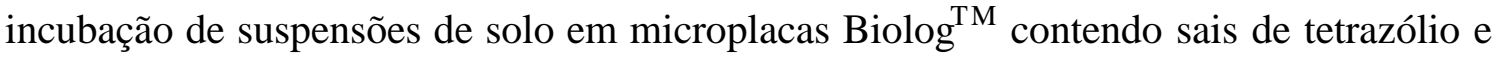
95 substratos de $\mathrm{C}$ diferentes (Zak et al., 1994). Mais recentemente, Biolog (Biolog, Hayward, CA, USA) introduziu a Ecoplate, que utiliza o mesmo princípio, porém com 31 substratos de $\mathrm{C}$ diferentes. Após a suspensão microbiana ser inoculada nas cavidades contendo os substratos, as placas são incubadas e a utilização de cada substrato é determinada pela absorbância a $590 \mathrm{~nm}$.

Com base na utilização de fontes de carbono por comunidades microbianas (Biolog), diferenças significativas na diversidade metabólica de comunidades advindas de amostras de solo distintas foram detectadas (Zak et al.,1994; Goodfriend, 1998 e Dauber \& Wolters, 2000). Neste contexto, diversidade metabólica é definida pelo número, tipo e taxa de utilização de um conjunto de substratos pela comunidade microbiana (Zak et al., 1994), e é uma conseqüência da diversidade genética, dos efeitos ambientais na expressão gênica, e das interações ecológicas entre as diferentes populações (Zak et al., 1994). Assim sendo, o estudo da diversidade metabólica da microbiota do solo pode servir como um indicador de mudanças de sua qualidade ou alterações em resposta a estresses.

Comparando características microbiológicas de dois solos distintos, um sob cultivo tradicional e outro sob pradaria não perturbada, Kennedy \& Smith (1995) verificaram que o sítio cultivado apresentava, em geral, maior diversidade microbiana, com base na habilidade de isolados microbianos utilizarem diversas fontes de carbono e crescerem na presença de metais pesados. 
Reduções da diversidade metabólica de comunidades microbianas do solo têm sido freqüentemente observadas após a adição de biossólidos de ETEs contaminados com metais (Banerjee et al., 1997). Da mesma forma, Reber (1992), trabalhando com estimativas de diversidade bacteriana e capacidade das bactérias do solo em utilizar substâncias aromáticas como fonte de carbono em solos contaminados com metais, verificou que, a diversidade metabólica decresceu em três dos cinco bioensaios realizados. Nos outros dois experimentos, nenhuma alteração ou maior diversidade nos solos contaminados com metais foi observada, devido, provavelmente, ao $\mathrm{pH}$ mais elevado, o qual pode ter indisponibilizado os metais, ou à seleção de estirpes de crescimento lento no solo controle.

A diversidade metabólica pode ser examinada de diferentes modos, analogamente aos conceitos empregados em diversidade taxonômica. Uma das formas mais simples é expressar a diversidade em termos de riqueza de substratos, ou seja, do número de diferentes substratos que podem ser utilizados pela comunidade microbiana. Outro índice utilizado é o de diversidade de Shannon (Zak et al.,1994; Goodfriend, 1998; Dauber \& Wolters, 2000; Lupwayi et al., 2001). O índice de diversidade de Shannon $(\mathrm{H})$ compreende tanto a riqueza de substratos quanto a intensidade com que esses substratos são usados pela microbiota, que é quantificada de acordo com a equação:

$\mathrm{H}=-\sum \mathrm{p}_{\mathrm{i}}\left(\ln \mathrm{p}_{\mathrm{i}}\right)$,

Onde:

$p_{i}$ é a razão entre a atividade de utilização de determinado substrato e a atividade de utilização de todos substratos.

Similarmente, a eqüitabilidade de substratos (E) mede a uniformidade de utilização de um substrato em relação ao número de substratos utilizados pela microbiota, e é dada por:

$\mathrm{E}=\frac{\mathrm{H}}{\ln \mathrm{S}}$

onde, 
S é o número de substratos utilizados e

H é o índice de diversidade de Shannon.

Lupwayi et al. (2001) avaliaram a diversidade metabólica das populações bacterianas de solos submetidos a diferentes manejos. Os autores empregaram uma placa Biolog com 95 substratos e demonstraram, através de análises de agrupamento e de componentes principais, que mudanças na estrutura da comunidade dos solos sob diferentes sistemas de manejo ocorriam.

Da mesma forma, Rasmussen e Sørensen (2001) utilizaram a placa ECOplate com 31 fontes de carbono (Biolog Inc.) para estudar o efeito da contaminação do solo por mercúrio sobre a diversidade metabólica da comunidade bacteriana do solo. A análise de componentes principais demonstrou que a comunidade bacteriana no solo contaminado com mercúrio apresentou um padrão uniforme de utilização de fontes de C, assim que a comunidade se adaptou à presença do mercúrio. Com exceção do primeiro dia, os perfis de utilização de fontes de $\mathrm{C}$ das amostras apresentaram alta similaridade. A similaridade no padrão de utilização na presença de mercúrio indica que a aplicação do metal resultou na seleção de umas poucas espécies com grande número de indivíduos, capazes de utilizar um largo espectro de fontes de carbono.

Desta maneira, pesquisas que contemplem o estudo da diversidade microbiana em solos contaminados são relevantes para avaliar a sustentabilidade da aplicação de biossólidos contendo metais em solos agrícolas. 


\section{MATERIAL E MÉTODOS}

\subsection{Instalação do Experimento}

O experimento foi instalado em casa-de-vegetação, em condições controladas de umidade, nas dependências do Departamento de Solos e Nutrição de Plantas da Escola Superior de Agricultura "Luiz de Queiroz", da Universidade de São Paulo. A temperatura foi monitorada desde o início do experimento, em 02/01/2001 (Figura 1). A temperatura média durante a primeira semana de incubação foi de $31,4{ }^{\circ} \mathrm{C}$; durante as 2 primeiras semanas de incubação foi de $32,8{ }^{\circ} \mathrm{C}$; durante as 4 primeiras semanas foi de $34,0{ }^{\circ} \mathrm{C}$; durante as 8 primeiras semanas foi de $33,0{ }^{\circ} \mathrm{C}$ e durante as 16 semanas foi de $34,3{ }^{\circ} \mathrm{C}$. A unidade experimental constituiu-se de vasos de $1 \mathrm{~L}$ de capacidade com $0,5 \mathrm{Kg}$ de solo.

O delineamento experimental constituiu-se de 4 doses de biossólidos da ETE-Franca, equivalentes a 03, 06, 12 e $24 \mathrm{~g} \mathrm{Kg}^{-1}$, correspondendo a 06, 12, 24 e 48 $\mathrm{Mg} \mathrm{ha}{ }^{-1}$, mantendo-se um controle sem adição de biossólido. Foram utilizadas 4 repetições por tratamento, compreendendo 20 sub-parcelas. Estas sub-parcelas foram incubadas por 1, 2, 4, 8 e 16 semanas, perfazendo um total de 120 parcelas.

\subsection{Biossólidos}

O biossólido foi coletado na ETE de Franca (SP), pertencente à Companhia de Saneamento Básico do Estado de São Paulo (SABESP), em pontos aleatórios das pilhas de biossólidos, a partir de amostras constituídas de 10 subamostras de volumes iguais. Essas amostras foram acondicionadas em câmara fria a $4{ }^{\circ} \mathrm{C}$ até o 
início do experimento. As características químicas do biossólido utilizado encontram-se na Tabela 1.

As quantidades de biossólido foram estipuladas conforme Norma da CETESB (CETESB, 1998), em função da quantidade de nitrogênio mineralizável, adotando-se uma taxa de mineralização de $20 \%$, valor recomendado para biossólidos estabilizados por digestão anaeróbia. Para a determinação da quantidade de $\mathrm{N}$ a ser aplicado adotaram-se as necessidades de uma cultura de milho para obtenção de uma produtividade média-alta (Raij et al., 1996).

Desta maneira, na dose equivalente a $6 \mathrm{Mg} \mathrm{ha}^{-1}$ foi adicionada a metade da quantidade máxima permitida de $\mathrm{N}$. A dose de $12 \mathrm{Mg} \mathrm{ha}^{-1}$ correspondeu à quantidade máxima permitida. Já a dose de $24 \mathrm{Mg} \mathrm{ha}^{-1}$ correspondeu a 2 vezes a quantidade máxima permitida e a dose de $48 \mathrm{Mg} \mathrm{ha}^{-1}$ a 4 vezes a quantidade máxima permitida. As respectivas quantidades de metais adicionadas, bem como os limites para aplicação anual, encontram-se na Tabela 2.

O biossólido foi adicionado a vasos de 1 litro de capacidade, contendo 500 gramas de solo argiloso (Nitossolo Vermelho Eutrófico Latossólico, Tabela 3 ). As sub-parcelas foram, então, incubadas em casa-de-vegetação por 1, 2, 4, 8, 16 semanas, mantendo-se a umidade do solo a $60 \%$ da capacidade máxima de retenção de água.

\subsection{Análises Laboratoriais}

Ao término de cada período de incubação, uma sub-parcela por tratamento foi coletada e utilizada para determinação do pH, C-biomassa, RB, RIS, $q \mathrm{CO}_{2}$ e diversidade metabólica.

\subsection{1 pH}

Das sub-parcelas previamente incubadas com biossólido da ETE-Franca, coletadas após 1, 2, 4, 8 e 16 semanas, retiraram-se 1 alíquota correspondente a $10 \mathrm{~g}$ de terra. Esta terra foi acondicionada em becker de $50 \mathrm{~mL}$ de capacidade, ao qual se 
adicionaram $25 \mathrm{~mL}$ de água destilada. As amostras foram agitadas por 5 minutos, procedendo-se a leitura do $\mathrm{pH}$ após 30 minutos, em potenciômetro Mettler Toledo MP 220.

\subsubsection{C-Biomassa}

Das sub-parcelas previamente incubadas com biossólido da ETE-Franca, coletadas após 1, 2, 4, 8 e 16 semanas, retiraram-se 2 alíquotas correspondentes a $10 \mathrm{~g}$ de terra, para determinação do C-biomassa pelo método da fumigação-extração (Vance et al, 1987). A primeira sub-amostra foi fumigada em dessecador contendo um becker com pérolas de vidro e clorofórmio. O clorofórmio foi evaporado sob vácuo. Após um período de 24 horas, procedeu-se a retirada do resíduo de clorofórmio do dessecador. A segunda sub-amostra serviu de controle (não-fumigada). Ambas subamostras receberam, então, $40 \mathrm{~mL}$ de $\mathrm{K}_{2} \mathrm{SO}_{4} 0,5 \mathrm{~mol} \mathrm{~L}{ }^{-1}$, sendo agitadas por 30 minutos. A suspensão resultante foi filtrada em papel de filtro Whatman $\mathrm{n}^{\mathrm{o}} 1$. O carbono orgânico dos extratos foi determinado pela digestão de $10 \mathrm{~mL}$ do filtrado com $1 \mathrm{~mL}$ de $\mathrm{K}_{2} \mathrm{Cr}_{2} \mathrm{O}_{7}$ e $10 \mathrm{~mL}$ de uma mistura de $\mathrm{H}_{2} \mathrm{SO}_{4}$ e $\mathrm{H}_{3} \mathrm{PO}_{4}$ concentrado (1:1), em erlenmeyers de $50 \mathrm{~mL}$. Esta solução permaneceu em banho-maria a $90^{\circ} \mathrm{C}$ durante uma hora. Após resfriadas, as amostras receberam $10 \mathrm{~mL}$ de $\mathrm{H}_{2} \mathrm{O}$ deionizada. $\mathrm{O}$ excesso de $\mathrm{K}_{2} \mathrm{Cr}_{2} \mathrm{O}_{7}$ foi determinado por titulação com sulfato ferroso de amônio, utilizando-se difenilamina sulfonato de bário como indicador. O C-Biomassa (CB) foi calculado da seguinte forma:

$$
\mathrm{CB}=2,64 \mathrm{Ec}
$$

sendo $\mathrm{Ec}=(\mathrm{C}$-orgânico extraído de solos fumigados $)-(\mathrm{C}$-orgânico extraído de solos não-fumigados).

Os dados foram expressos em $\mu \mathrm{g} \mathrm{g}^{-1}$ de solo seco.

\subsubsection{Respiração Basal}

Das sub-parcelas previamente incubadas com biossólido da ETE-Franca, coletadas após 1, 2, 4, 8 e 16 semanas, retirou-se o equivalente a 50 g de terra, 
incubando-se em frascos de vidro providos de tampas plásticas vedantes. A umidade foi corrigida para $60 \%$ da capacidade máxima de retenção de água. Sobre a superfície do solo, em cada frasco de vidro, foi colocado um frasco contendo $10 \mathrm{~mL}$ de solução de $\mathrm{NaOH}$ 0,5 mol L-1 , para absorver o $\mathrm{CO}_{2}$ liberado do solo. Após 24 horas de incubação a $28{ }^{\circ} \mathrm{C}$, retirou-se o frasco com a solução de $\mathrm{NaOH}$ e adicionou-se $1 \mathrm{~mL}$ de $\mathrm{BaCh}$ e 3 gotas do indicador fenoftaleína. A quantidade de $\mathrm{CO}_{2}$ liberado do solo foi determinada após titulação do excedente de $\mathrm{NaOH}$ com solução de $\mathrm{HCl} 0,5 \mathrm{~mol} \mathrm{~L}^{-1}$. Os resultados obtidos foram expressos em $\mu \mathrm{g}$ de C- $\mathrm{CO}_{2} \mathrm{~g}^{-1}$ solo seco hora ${ }^{-1}$.

\subsubsection{Respiração Induzida pelo Substrato}

Das sub-parcelas previamente incubadas com biossólido da ETE-Franca, coletadas após 1, 2, 4, 8 e 16 semanas, retirou-se o equivalente a $50 \mathrm{~g}$ de terra, incubando-se em frascos de vidro providos de tampas plásticas vedantes. Às amostras de solo nos respirômetros, adicionaram-se 0,5\% (em massa) de glicose anidra. A umidade foi corrigida para $60 \%$ da capacidade máxima de retenção de água. Sobre a superfície do solo, em cada frasco de vidro, foi colocado um frasco contendo $10 \mathrm{~mL}$ de solução de

$\mathrm{NaOH}$ 0,5 mol L ${ }^{-1}$, para absorver o $\mathrm{CO}_{2}$ liberado do solo. Após 24 horas de incubação a $28{ }^{\circ} \mathrm{C}$, retirou-se o frasco com a solução de $\mathrm{NaOH}$ e adicionou-se $1 \mathrm{~mL}$ de $\mathrm{BaCb}_{2}$ e 3 gotas do indicador fenoftaleína. A quantidade de $\mathrm{CO}_{2}$ liberada foi determinada por titulação do $\mathrm{NaOH}$ excedente com solução de $\mathrm{HCl} 0,5 \mathrm{~mol} \mathrm{~L}^{-1}$. Os resultados obtidos foram expressos em $\mu \mathrm{g}$ de $\mathrm{C}-\mathrm{CO}_{2} \mathrm{~g}^{-1}$ solo seco hora ${ }^{-1}$.

\subsubsection{Quociente Metabólico $\left(q \mathrm{CO}_{2}\right)$}

Foi calculado como a razão entre o $\mathrm{C}-\mathrm{CO}_{2}$ liberado na respiração basal e o C-biomassa. Deve-se ressaltar que, para a análise estatística, os dados foram transformados utilizando-se a raiz quadrada, para que seguissem uma distribuição normal. 


\subsubsection{Diversidade Metabólica}

Das sub-parcelas previamente incubadas com biossólido da ETE-Franca, coletadas após 1, 2, 4, 8 e 16 semanas, retirou-se o equivalente a $10 \mathrm{~g}$ de terra, adicionando-a a erlenmeyers contendo $90 \mathrm{~mL}$ de uma solução salina $(\mathrm{NaCl}$ 0,85\%) esterilizada. Estas suspensões foram, então, dispersas por 10 minutos em agitador orbital. Após aguardar 10 minutos, $1 \mathrm{~mL}$ do sobrenadante foi diluído em $9 \mathrm{~mL}$ da solução salina. Alíquotas de $0,1 \mathrm{~mL}$ de suspensões de $10^{-3}$ a $10^{-7}$ foram utilizadas para determinação do Número Mais Provável de bactérias heterotróficas, em meio nutriente. $100 \mu \mathrm{L}$ de uma suspensão contendo $10^{2}-10^{3}$ células bacterianas por $\mathrm{mL}$ foram adicionados às cavidades das microplacas Biolog ECO (Biolog Inc., Hayward, Califórnia). Para cada repetição utilizou-se uma microplaca. Cada microplaca Biolog contém 31 fontes de carbono (com 3 repetições) amplamente utilizadas por microrganismos do solo e similares à fontes de $\mathrm{C}$ encontradas normalmente nos solos, e 1 cavidade sem nenhuma fonte de carbono (controle negativo, com água), além do corante tetrazólio violeta (Quadro 1). As placas foram incubadas a $28^{\circ} \mathrm{C}$ por 72 horas. $\mathrm{O}$ crescimento microbiano foi determinado por espectrofotometria a $595 \mathrm{~nm}$ utilizando-se um espectrofotômetro para microplacas (Microplate Reader Benchmark, Biorad).

A capacidade ou não da microbiota em utilizar uma determinada fonte de C foi definida de acordo com Ibekwe \& Kennedy (1998), utilizando-se a equação:

$\mathrm{W}_{\mathrm{E}}=\frac{\left(\mathrm{W}_{\mathrm{A}}-\mathrm{W}_{\mathrm{o}}\right)}{\mathrm{W}_{\mathrm{o}}} * 100$

Onde,

$\mathrm{W}_{\mathrm{E}}$ é o índice de desenvolvimento da cor;

$\mathrm{W}_{\mathrm{A}}$ é a absorbância de cada cavidade e

$\mathrm{W}_{\mathrm{o}}$ é a absorbância da cavidade controle.

Valores de $\mathrm{W}_{\mathrm{E}}$ maiores do que 100 foram considerados reações positivas (evidência da utilização de substrato) e valores de $\mathrm{W}_{E}$ menores do que 100 foram considerados reações negativas. Os dados de utilização de substratos foram convertidos 
em uma planilha binária e utilizados para análises de agrupamento, através do programa Gene Cluster e Treeview (Eisen et al., 1998).

O Metabolismo Heterotrófico Médio (MHM), para cada fonte de carbono foi calculado de acordo com Garland (1996). O Índice de Diversidade de Shannon (H), que compreende tanto a riqueza de substratos como a intensidade com que são usados pela microbiota foi calculada de acordo com Zak et al.(1994), utilizando a equação:

$\mathrm{H}=-\sum \mathrm{p}_{\mathrm{i}}\left(\ln \mathrm{p}_{\mathrm{i}}\right)$

Onde,

$\mathrm{p}_{\mathrm{i}}$ é a razão entre a atividade de utilização de determinado substrato e a atividade de utilização de todos substratos.

A riqueza de substratos $(\mathrm{S})$ foi determinada através do número total de substratos utilizados $\left(\mathrm{W}_{\mathrm{e}}>100\right)$ pela comunidade microbiana do solo. A eqüitabilidade de substratos (E), que mede a uniformidade de utilização de um substrato em relação ao número de substratos utilizados pela microbiota, foi calculada de acordo com a equação:

$\mathrm{E}=\frac{\mathrm{H}}{\ln \mathrm{S}}$

Onde,

S é o número de substratos utilizados e

H é o índice de diversidade de Shannon.

Deve-se ressaltar que, para a análise estatística, os dados de eqüitabilidade foram transformados utilizando-se arc sen, para que seguissem uma distribuição normal.

\subsubsection{Análises Estatísticas}

Os dados de pH, C-biomassa, Respiração, $q \mathrm{CO}_{2}$, Índices de Diversidade Metabólica e Desenvolvimento Médio da Cor foram submetidos à análise de variância $(\mathrm{p} \leq 0,05)$. As comparações de médias foram feitas através do teste de Tukey $(\mathrm{p} \leq 0,05)$, 
utilizando-se o pacote estatístico Systat 8.0. A análise de agrupamento hierárquico foi feita utilizando-se o programa Gene Cluster e Treeview (Eisen et al.,1998), após normalização dos dados. Os coeficientes de similaridade foram determinados utilizandose uma distribuição binária dos dados (ausência (0) ou presença (1) de cor como indicativo de atividade, através de coeficientes "simple matching", utilizando-se o pacote estatístico Systat 8.0. 


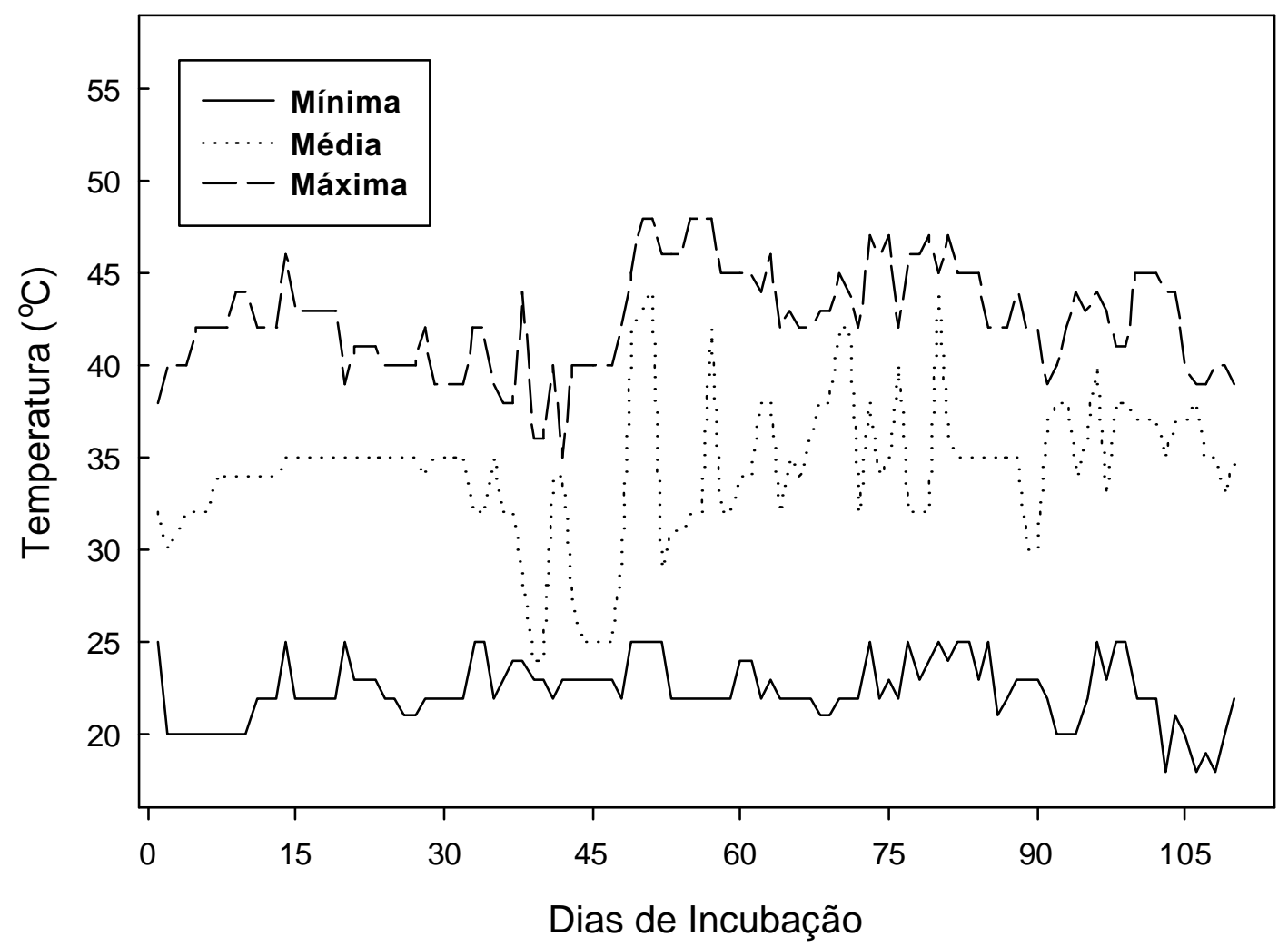

Figura 1 - Variação diária da temperatura em casa-de-vegetação utilizada para realização do experimento, no período de 02/01 a 15/04/2001. 
Tabela 1. Características do biossólido da ETE-Franca

\begin{tabular}{lr}
\hline \multicolumn{1}{c}{ Parâmetro } & Base seca \\
& $\left(110^{\circ} \mathrm{C}\right)$ \\
\hline $\mathrm{pH}$ em CaCb $0,01 \mathrm{M}$ & 7,8 \\
Umidade Total & $84,25 \%$ \\
Umidade perdida a $60-65^{\circ} \mathrm{C}$ & $835,4 \%$ \\
Carbono total & $414,60 \mathrm{~g} \mathrm{~kg}^{-1}$ \\
Carbono Orgânico & $410,80 \mathrm{~g} \mathrm{~kg}^{-1}$ \\
Resíduo Mineral total & $254,00 \mathrm{~g} \mathrm{~kg}^{-1}$ \\
Resíduo Mineral Insolúvel & $94,0 \mathrm{~g} \mathrm{~kg}^{-1}$ \\
Resíduo Mineral Solúvel & $160,00 \mathrm{~g} \mathrm{~kg}^{-1}$ \\
Nitrogênio total & $56,5 \mathrm{~g} \mathrm{~kg}^{-1}$ \\
Fósforo total & $13,01 \mathrm{~g} \mathrm{~kg}^{-1}$ \\
Potássio total & $1,1 \mathrm{~g} \mathrm{~kg}^{-1}$ \\
Cálcio total & $14,0 \mathrm{~g} \mathrm{~kg}^{-1}$ \\
Magnésio total & $1,9 \mathrm{~g} \mathrm{~kg}^{-1}$ \\
Enxofre total & $4,4 \mathrm{~g} \mathrm{~kg}^{-1}$ \\
Zinco total & $1046 \mathrm{mg} \mathrm{kg}^{-1}$ \\
Ferro total & $24019 \mathrm{mg} \mathrm{kg}^{-1}$ \\
Cobre total & $207 \mathrm{mg} \mathrm{kg}^{-1}$ \\
Manganês total & $190 \mathrm{mg} \mathrm{kg}^{-1}$ \\
Crômio total & $949 \mathrm{mg} \mathrm{kg}^{-1}$ \\
Níquel total & $47 \mathrm{mg} \mathrm{kg}^{-1}$ \\
Relação C-orgânico/ N total & \\
\hline
\end{tabular}


Tabela 2. Taxa máxima anual permitida pela Norma P4.230 da CETESB (Estado de São Paulo, 1999) e taxa de metais aplicada no solo, de acordo com as doses estipuladas.

\begin{tabular}{cccccc}
\hline Metal & $\begin{array}{c}\text { Taxa Máxima } \\
\text { Anual }\end{array}$ & \multicolumn{4}{c}{$\begin{array}{c}\text { Dose de biossólido aplicada no solo } \\
\left(\mathrm{Mg} \mathrm{ha}^{-1}\right)\end{array}$} \\
\cline { 3 - 6 }$\left(\mathrm{kg} \mathrm{ha}^{-1}\right)$ & 6 & 12 & 24 & 48 \\
\hline Cobre & 75 & 1,22 & 2,44 & 4,88 & 9,44 \\
Crômio & $*$ & 5,69 & 11,38 & 22,77 & 45,52 \\
Níquel & 21 & 0,28 & 0,56 & 1,13 & 2,25 \\
Zinco & 140 & 6,27 & 12,55 & 25,10 & 50,2 \\
\hline
\end{tabular}

* Deve-se respeitar o limite cumulativo máximo de $1000 \mathrm{~kg} \mathrm{ha}^{-1}$ (Estado de São Paulo, 1999). Os valores estão expressos em $\mathrm{kg} \mathrm{ha}^{-1}$. 
Tabela 3. Análise Química e Granulométrica do Nitossolo Vermelho Eutrófico Latossólico utilizado no experimento.

\begin{tabular}{|c|c|}
\hline Características & $\begin{array}{l}\text { Nitossolo Vermelho } \\
\text { Eutrófico Latossólico }\end{array}$ \\
\hline $\mathrm{pH}$ em $\mathrm{CaCl}_{2} 0,01 \mathrm{M}$ & 4,9 \\
\hline M.O. $\left(\mathrm{g} \mathrm{dm}^{-3}\right)$ & 30 \\
\hline$P\left(\mathrm{mg} \mathrm{dm}^{-3}\right)$ & 24 \\
\hline $\mathrm{S}-\mathrm{SO}_{4}\left(\mathrm{mg} \mathrm{dm}^{-3}\right)$ & 38 \\
\hline $\mathrm{K} \quad\left(\right.$ mmolc $\left.\mathrm{dm}^{-3}\right)$ & 4,3 \\
\hline $\mathrm{Ca}\left(\mathrm{mmolc} \mathrm{dm}^{-3}\right)$ & 52 \\
\hline $\operatorname{Mg}\left(\right.$ mmolc $\left.\mathrm{dm}^{-3}\right)$ & 18 \\
\hline $\mathrm{H}+\mathrm{Al}\left(\mathrm{mmolc} \mathrm{dm}^{-3}\right)$ & 42 \\
\hline $\mathrm{SB}\left(\mathrm{mmolc} \mathrm{dm}^{-3}\right)$ & 74,3 \\
\hline $\mathrm{T}\left(\mathrm{mmolc} \mathrm{dm}^{-3}\right)$ & 116,3 \\
\hline $\mathrm{V}(\%)$ & 64 \\
\hline$B\left(\mathrm{mg} \mathrm{dm}^{-3}\right)$ & 0,26 \\
\hline $\mathrm{Cu}\left(\mathrm{mg} \mathrm{dm} \mathrm{d}^{-3}\right)$ & 12,8 \\
\hline $\mathrm{Fe}\left(\mathrm{mg} \mathrm{dm}^{-3}\right)$ & 43 \\
\hline $\operatorname{Mn}\left(\mathrm{mg} \mathrm{dm} \mathrm{m}^{-3}\right)$ & 123 \\
\hline $\mathrm{Zn}\left(\mathrm{mg} \mathrm{dm} \mathrm{m}^{-3}\right)$ & 5,6 \\
\hline Areia Total (\%) & 29 \\
\hline Silte $(\%)$ & 14 \\
\hline Argila Total (\%) & 57 \\
\hline
\end{tabular}

$\mathrm{S}-\mathrm{SO}_{4}=\mathrm{NH}_{4} \mathrm{OAc} 0,5 \mathrm{~N}$ em HOAc $0,25 \mathrm{~N}(10 \mathrm{~mL}$ TFSA/25mL);

$\mathrm{Cu}, \mathrm{Fe}, \mathrm{Mn}, \mathrm{Zn}$ - DTPA - TEA; pH, 7,3; $\mathrm{B}=\mathrm{BaCl}_{2} .2 \mathrm{H}_{2} \mathrm{O} 0,125 \%$

microondas (10mL TFSA/20mL $\mathrm{BaCl}_{2}$ 0,125\%). 


\begin{tabular}{|c|c|}
\hline $\begin{array}{c}\text { № da Fonte de } \\
\text { Carbono }\end{array}$ & Nome da Fonte de Carbono \\
\hline 1 & Éster Metílico do Ácido Pirúvico \\
\hline 2 & Tween 40 \\
\hline 3 & Tween 80 \\
\hline 4 & $\alpha$-Ciclodextrina \\
\hline 5 & Glicogênio \\
\hline 6 & D-Celobiose \\
\hline 7 & $\alpha$-D-Lactose \\
\hline 8 & $\beta$-Metil-D-Glicosídeo \\
\hline 9 & D-Xilose \\
\hline 10 & i-Eritritol \\
\hline 11 & D-Manitol \\
\hline 12 & N-Acetil-D-Glicosamina \\
\hline 13 & Ácido-D-glicosamínico \\
\hline 14 & Glicose-1-fosfato \\
\hline 15 & D,L- $\alpha$-Glicerol fosfato \\
\hline 16 & Ácido D-Galacturônico $\gamma$-Lactona \\
\hline 17 & Ácido D-Galacturônico \\
\hline 18 & Ácido 2-Hidroxibenzóico \\
\hline 19 & Ácido 4-Hidroxibenzóico \\
\hline 20 & Ácido $\gamma$-Hidroxibutírico \\
\hline 21 & Ácido Itacônico \\
\hline 22 & Ácido $\alpha$-Cetobutírico \\
\hline 23 & Ácido D-Málico \\
\hline 24 & L-Arginina \\
\hline 25 & L-Asparagina \\
\hline 26 & L-Fenilalanina \\
\hline 27 & L-Serina \\
\hline 28 & L-Treonina \\
\hline 29 & Ácido Glicil-L-glutâmico \\
\hline 30 & Feniletilanina \\
\hline 31 & Putrescina \\
\hline
\end{tabular}

Quadro 1- Denominação das fontes de carbono contidas nas microplacas Biolog. 


\section{RESULTADOS E DISCUSSÃO}

\section{$4.1 \mathrm{pH}$}

$\mathrm{O} \mathrm{pH}$ do solo foi significativamente $(\mathrm{p} \leq 0,05)$ afetado pela adição de biossólido. $\mathrm{Na} 1^{\underline{a}}$ semana de incubação, todos os tratamentos com biossólidos promoveram um acréscimo significativo no $\mathrm{pH}$, em relação ao controle sem biossólido. $\mathrm{Na} 2^{\mathrm{a}}$ semana, os solos que receberam as quantidades correspondentes a 12,24 e $48 \mathrm{Mg}$ $\mathrm{ha}^{-1}$ de biossólidos apresentaram valores de $\mathrm{pH}$ significativamente maiores $(\mathrm{p} \leq 0,05)$ do que o controle sem biossólido. Já com 4 semanas de incubação, o pH dos solos tratados com biossólidos não diferiu significativamente do controle, sem biossólido $(\mathrm{p} \leq 0,05)$. Com 8 semanas de incubação, todos os solos tratados com biossólidos apresentaram um drástica redução do $\mathrm{pH}$, sendo significativamente diferentes do controle, sem biossólido. Este comoportamento se estende até o final do período de incubação com 16 semanas (Figura 2).

O incremento inicial do pH do solo após adição de resíduos orgânicos, em relação ao solo controle sem adição pode ser atribuído a dois fatores. O primeiro é a descarboxilação de ânions orgânicos acumulada nestes materiais. Ânions orgânicos são reservas alcalinas em potencial, podendo causar incremento no $\mathrm{pH}$ quando a decomposição ocorre devido à atividade microbiana. Um segundo processo que pode causar incremento no pH do solo é a desaminação de amino-ácidos (Yan et al.,1996).

Incremento no $\mathrm{pH}$ do solo pode ser também causado por ligantes de troca entre grupos hidroxilas de alumínio ou hidróxidos de ferro, e ânions orgânicos adicionados (Hue \& Amien, 1989).

Entretanto, a adição de cátions é também uma hipótese plausível, já que estes cátions deslocam prótons e alumínio dos sítios de troca, contribuindo, então, para o 


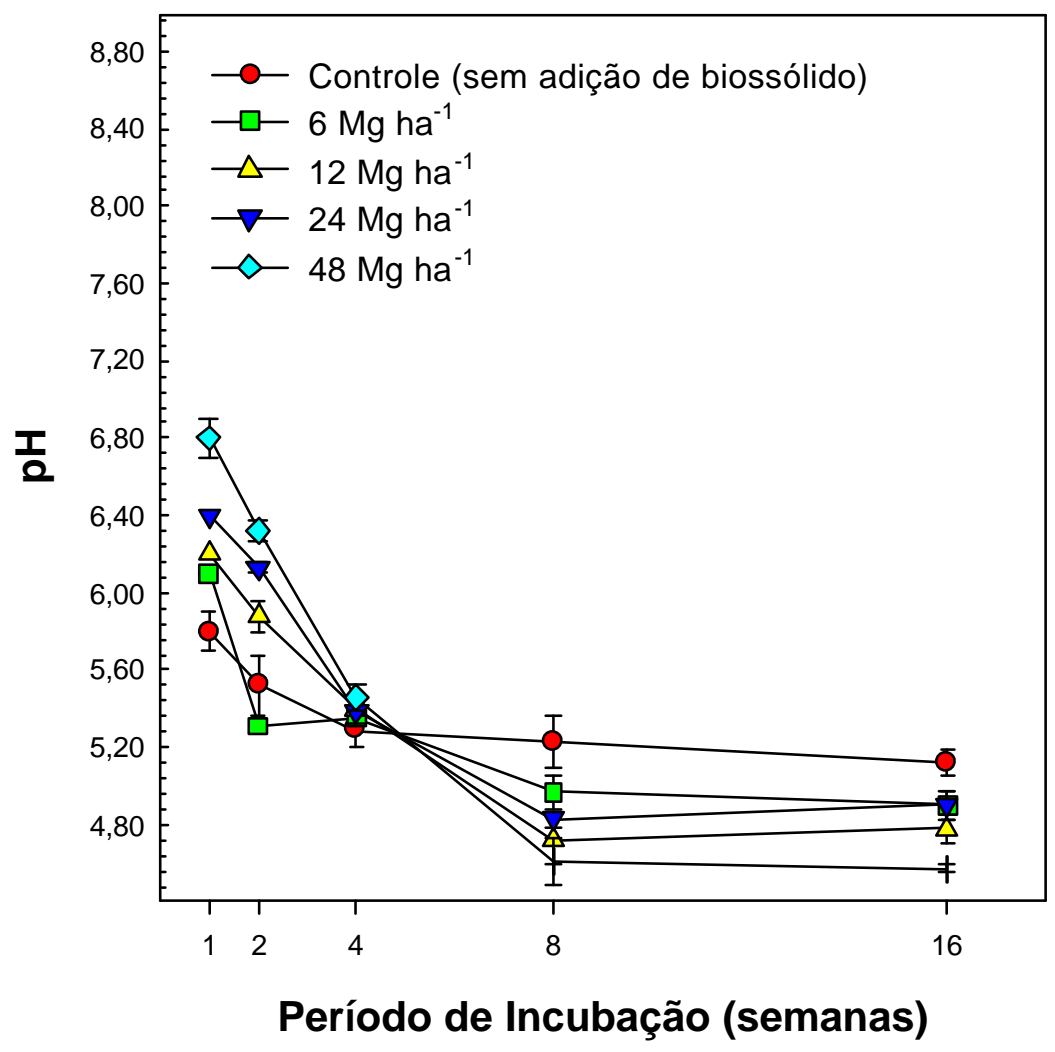

Figura 2 - Valores de pH de solo argiloso contendo biossólido da ETE-Franca, em função do período de incubação. Os dados são médias de 4 repetições \pm desvio padrão da média. 
aumento da saturação de bases do solo, e, consequentemente, para o incremento do $\mathrm{pH}$ do solo.

Concentrações significativamente mais elevadas de $\mathrm{NH}_{4}{ }^{+}$em solos que receberam biossólidos da ETE-Franca em quantidades similares ao deste estudo foram observadas por Carmo (2000), ao avaliar o impacto da aplicação de biossólidos nas atividades microbianas do solo. Esta autora observou, da mesma forma, aumentos significativos de pH logo após a aplicação, em relação ao solo controle, sem adição de biossólido, o qual diminuiu com o período de incubação, atingindo valores inferiores ao do solo sem adição de biossólido (controle).

Normalmente, o aumento inicial do $\mathrm{pH}$ do solo após a incorporação de resíduos orgânicos é seguida de diminuição desses valores, provavelmente devido ao processo de nitrificação (Yan et al., 1996). O amônio é oxidado a nitrito e nitrato, com a produção líquida de dois íons $\mathrm{H}^{\dagger}$ e conseqüente redução do $\mathrm{pH}$. A redução do $\mathrm{pH}$ observada em solo com a maior quantidade de biossólido adicionada ao final do período de incubação é devida, provavelmente, ao processo de nitrificação. Neste experimento, os menores valores de $\mathrm{pH}$ observados nos tratamentos com a maior concentração de biossólidos, após 16 semanas de incubação, sugerem taxas de nitrificação mais elevadas. Em experimento similar, Carmo (2000) de fato observou taxas de nitrificação mais elevadas em solos que receberam o equivalente a 12, 24, 48 e $96 \mathrm{Mg} \mathrm{ha}^{-1}$ após 32 dias da adição do biossólido da ETE-Franca. Estes valores acompanharam um decréscimo significativo do $\mathrm{pH}$ do solo para os mesmos tratamentos.

Da mesma forma, Stamatiadis et al. (1999), estudando aspectos da qualidade do solo que se alteram devido à adição de biossólidos com alto teor de água, encontraram uma queda de 0,4 unidades no $\mathrm{pH}$ do solo que havia recebido biossólidos, em relação ao solo controle, atribuindo esta queda ao processo de nitrificação do amônio.

Khan \& Scullion (1999) obtiveram resultados similares ao estudar a adição de biossólidos com baixas, médias e altas concentrações de metais em solos sob pastagens. Observaram poucas alterações no $\mathrm{pH}$ do solo logo após a aplicação de biossólidos, e menor acidificação significativa entre 3 e 7 semanas de incubação. No 
entanto, atribuíram este declínio ao incremento das quantidades de metais adicionadas e não ao processo de nitrificação.

\subsection{C-Biomassa}

O C-biomassa dos solos com diferentes quantidades de biossólidos pode ser observado na Figura 3. Na $1^{\underline{a}}, 2^{2}$ e $4^{\underline{a}}$ semanas de incubação, verifica-se que esta variável foi significativamente maior $(\mathrm{p} \leq 0,05)$, em relação ao controle sem biossólido, apenas no solo que recebeu o equivalente a $48 \mathrm{Mg} \mathrm{ha}^{-1}$. Nos demais tratamentos, o Cbiomassa não difere estatisticamente $(\mathrm{p} \leq 0,05)$ do controle, sem biossólidos. Com 8 e 16 semanas, o C-biomassa dos solos com biossólido não diferiu do controle sem biossólidos $((\mathrm{p} \leq 0,05)$.

O aumento inicial no C-biomassa nos solos com a maior quantidade de biossólido adicionado pode ser explicado pelo incremento no conteúdo de matéria orgânica e nutrientes no solo, o que favoreceu o crescimento microbiano.

Banergee et al. (1997), avaliando o impacto da aplicação de biossólidos nas características biológicas do solo, observaram que, no geral, o C-biomassa também apresentou incrementos significativos, em relação ao solo sem aplicação de biossólidos. Neste caso, o biossólido continha quantidades de metais abaixo das estipuladas pelas normas de aplicação, similar ao biossólido utilizado em nosso experimento.

Aumentos significativos e lineares nos teores de C-biomassa, em função da adição de lodo de curtume também foram observados por Jahnel (1999) ao estudar parâmetros microbiológicos da degradação do lodo. Este autor verificou também, que a quantidade de C-biomassa diminuiu ao longo do período estudado (63 dias), atribuindo esta queda ao consumo da matéria orgânica.

Da mesma forma, diferenças nas respostas do C-biomassa em função do período de incubação foram relatadas por Chander et al. (1991). Estes autores adicionaram biossólidos ao solo e incubaram por 1, 4, 8 e 64 semanas observando declínios significativos no C-biomassa ao final do período de incubação no solo controle. 


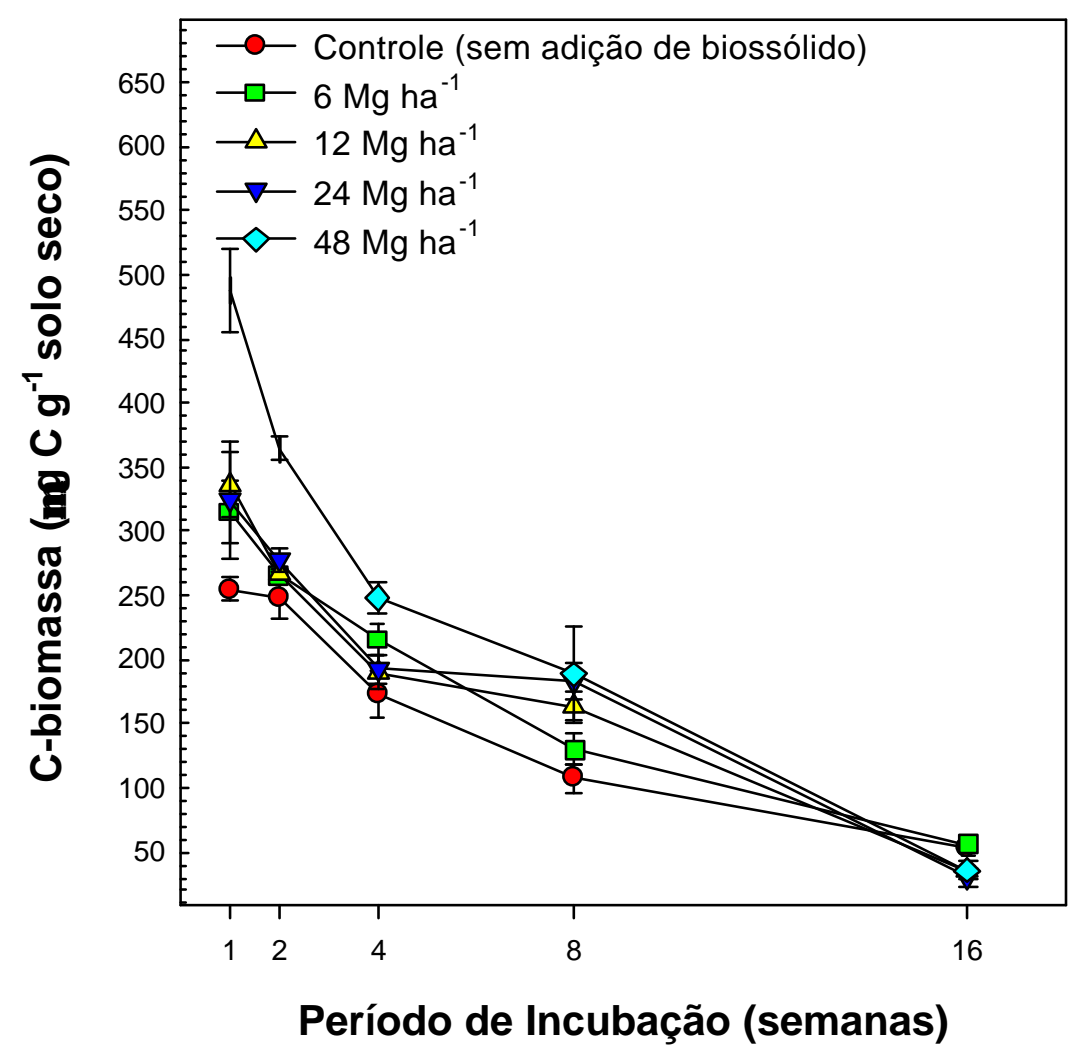

Figura 3 - Variação do Carbono na biomassa microbiana (C-biomassa) em solo argiloso contendo biossólido da ETE-Franca, em função do período de incubação. Os dados são médias de 4 repetições \pm desvio padrão da média. 
Para os tratamentos que receberam biossólidos, independente da taxa de aplicação e da quantidade de metais, incrementos significativos na quantidade de Cbiomassa foram observados na primeira e quarta semana de incubação. Após 4 semanas os valores decrescem e não diferem do controle após 16 semanas, provavelmente devido à exaustão do carbono orgânico lábil (Chander et al.,1991).

Avaliando o impacto da aplicação de biossólidos da ETE-Franca nas atividades microbianas do solo, em doses similares ao deste estudo, Carmo (2000) observou incrementos significativos no C-biomassa no início do período de incubação, sugerindo que não houve efeito inibitório de espécies químicas possivelmente tóxicas, constituintes dos materiais orgânicos adicionados.

Diminuição na biomassa microbiana do solo que continha grandes quantidades de elementos potencialmente tóxicos, como metais pesados, foi observado por Brookes \& McGrath (1984), que atribuíram essa diminuição a um possível efeito tóxico desses elementos.

Da mesma forma, Fortes Neto (2000) avaliando a degradação de biossólido proveniente da ETE-Barueri, rico em metais, em solos florestais, observou valores significativamente menores de C-biomassa nos tratamentos que receberam 40 e $60 \mathrm{Mg} \mathrm{ha}^{-1}$ de biossólido, em relação ao controle sem biossólido, principalmente entre 30 e 150 dias após a aplicação. Atribuiu estes resultados a baixa relação C/N (9:1) do biossólido, reponsável pela maior perda de carbono via respiração, ao invés de ser imobilizado pela microbiota do solo. Essa redução poderia ter sido causada também por efeitos tóxicos de metais sobre a microbiota do solo.

Avaliando os efeitos da aplicação de biossólidos no C-biomassa, Chander e Brookes (1991) reportaram que o C- biomassa diminui em solos tratados com biossólidos ricos em metais e que essa redução é maior em solos arenosos, do que em solos argilosos. Khan \& Scullion (2000), da mesma forma, encontraram decréscimos na biomassa microbiana em solos arenosos contaminados com metais. Neste caso, o Cbiomassa da microbiota apresentou correlação negativa com a concentração de metais no solo. No entanto, essa correlação não foi observada em solos argilosos, sugerindo que a disponibilidade de metais pode ser menor em solos com maior teor de colóides. Carmo 
(2000), adicionando biossólido da ETE-Franca a um solo argiloso observou, também, aumentos transientes do C-biomassa do solo, sugerindo que o biossólido da ETE-Franca não inibe a atividade de síntese da biomassa microbiana.

Menores taxas de C-biomassa foram observadas por Diaz Júnior (1996), em solos contaminados com metais pesados, em relação ao solo controle. Este decréscimo foi atribuído à elevada contaminação, ausência de vegetação e baixo teor de carbono. Solos altamente contaminados, porém com elevados teores de carbono orgânico, apresentaram valores de C-biomassa similares ao solo controle, sugerindo uma complexação de metais. A matéria orgânica do solo constitui a força geradora de energia utilizada nos processos metabólicos realizados pela população microbiana envolvendo vários nutrientes essenciais, constituindo fonte de energia e $\mathrm{C}$ para o crescimento e metabolismo da população microbiana (Bolton et al.,1992).

Em nosso estudo, os maiores valores de C-biomassa encontrados nos solos com a maior quantidade de biossólido adicionado, no início do período de incubação, com a posterior queda no decorrer do período, sugerem que a matéria orgânica foi responsável pelo incremento inicial e que essa biomassa foi rapidamente reciclada no solo

\subsection{Respiração Basal e Respiração Induzida pelo Substrato}

A RB reflete a atividade da microbiota do solo responsável pela degradação de compostos orgânicos, e foi avaliada pela liberação de $\mathrm{CO}_{2}$ (Figura 4). Com 1 semana de incubação, a RB é significativamente maior $(\mathrm{p} \leq 0,05)$, em relação ao controle sem adição de biossólido, quando da adição do equivalente a 24 e $48 \mathrm{Mg} \mathrm{ha}^{-1}$ de biossólido. Este comportamento é observado até a 2a semana de incubação. Com 4 semanas de incubação, apenas o solo que recebeu a quantidade equivalente a $48 \mathrm{Mg} \mathrm{ha}^{-1}$ difere do controle sem biossólido. Já com 8 semanas de incubação, a RB em todos os tratamentos com biossólidos não difere do controle. Ao final do período de incubação (16 semanas), entretanto, a RB nos solos que receberam biossólido volta a superar a do controle $(\mathrm{p} \leq 0,05)$. 


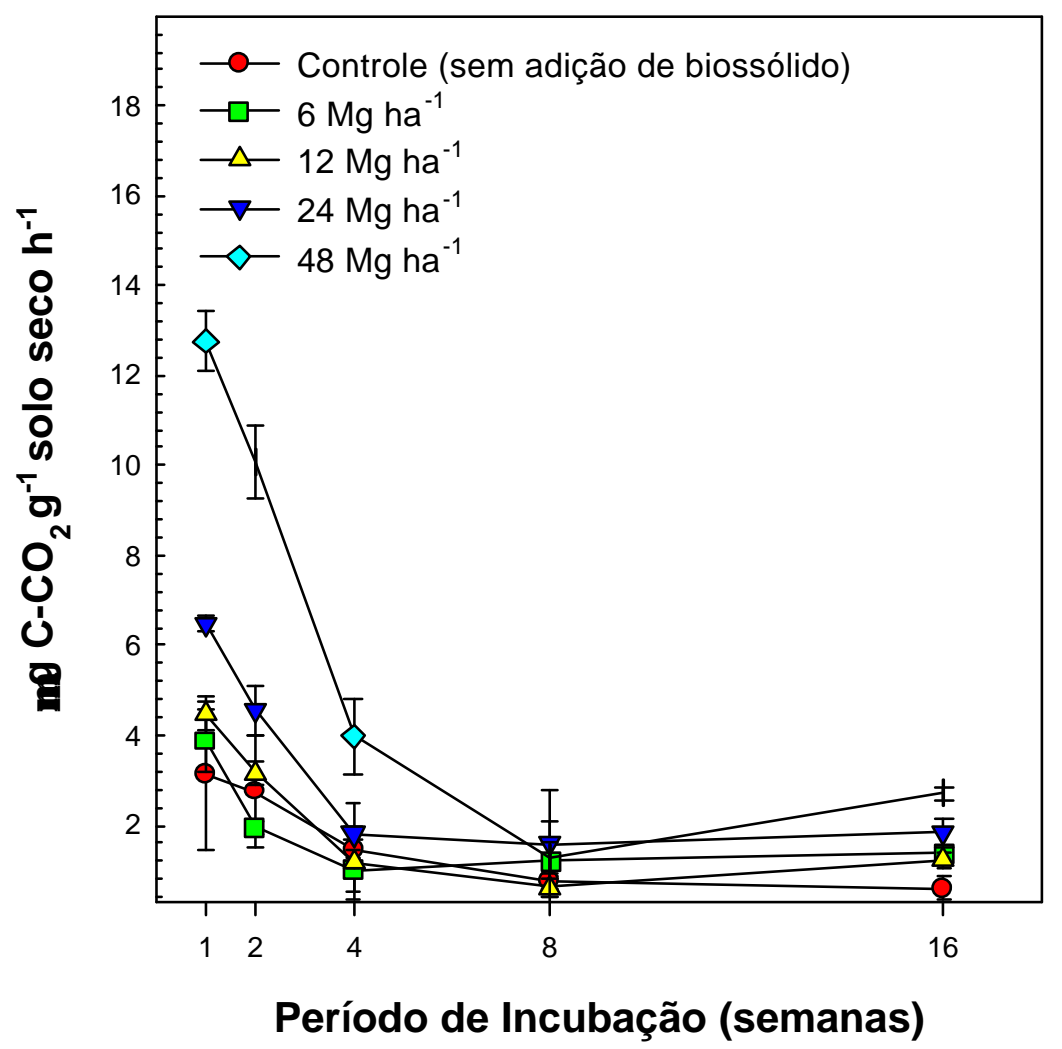

Figura 4 - Variação da Respiração Basal (RB) em solo argiloso contendo biossólido da ETE- Franca, em função do período de incubação. Os dados são médias de 4 repetições \pm desvio padrão da média. 
Os dados observados podem ser explicados pelo incremento no conteúdo de matéria orgânica e nutrientes do solo, estimulando a atividade microbiana (Emmerling, et al, 2000) e, ainda à maior ciclagem da biomassa microbiana, ocasionando, assim o aumento da RB (Chander \& Brookes, 1993; Leita et al., 1995).

Stamatiadis et al. (1999), avaliando alterações na qualidade de solos que haviam recebido biossólidos, observaram que a respiração do solo foi 4 vezes maior no solo com biossólidos, do que no controle sem biossólido.

Ao avaliar o efeito da adição de lodo de curtume em solo argiloso e arenoso, Jahnel (1999) observou acréscimos significativos na liberação de $\mathrm{CO}_{2}$ em função do aumento da dose aplicada. Mesmo a presença de altos teores de crômio não afetou significativamente a RB do solo . O autor atribui este fato ao efeito estimulante da matéria orgânica e de nutrientes aos microrganismos do solo.

A RB também foi avaliada por Carmo (2000), ao estudar o impacto da aplicação de biossólidos da ETE-Franca em solo argiloso. Nos tratamentos com as maiores quantidades de biossólido adicionado observaram-se aumentos siginificativos da RB foram observados até o $8^{\underline{0}}$ dia de incubação. Após 8 dias de incubação, a RB nos solos com biossólidos não diferem mais do controle sem adição de biossólido. Vale ressaltar que as doses utilizadas eram similares ao do presente estudo.

Da mesma forma, Caldeira (1997), avaliando a cinética de degradação de biossólidos, encontrou liberações significativamente maiores de $\mathrm{CO}_{2}$ para os solos que receberam biossólidos, em relação à testemunha, sem adição de biossólido. Estes valores atingem um pico por volta de 25 dias, quando então começam a decair devido, provavelmente, à exaustão do carbono orgânico.

A Respiração Induzida pelo Substrato (RIS) reflete a atividade de microrganismos zimógenos, os quais respondem à adição de matéria orgânica ao solo (Anderson \& Domsch, 1978). Esta medida é particularmente útil para avaliar o impacto de substâncias potencialmente tóxicas sobre a microbiota dos solos.

Na Figura 5 podemos observar um incremento significativo $(\mathrm{p} \leq 0,05)$ da RIS nos solos de todos os tratamentos com biossólidos, na $1^{\underline{a}}$ primeira semana de incubação, em relação ao controle sem biossólido. Este comportamento se prolonga até 
4 semanas após a adição de biossólidos. Após 8 semanas de incubação, apenas no solo com o equivalente a $48 \mathrm{Mg} \mathrm{ha}^{-1}$ a RIS é mais elevada do que no controle. Já após 16 semanas de incubação, a RIS dos solos que receberam o equivalente a 24 e $48 \mathrm{Mg} \mathrm{ha}^{-1}$ de biossólido apresenta-se significativamente maior em relação ao controle $(\mathrm{p} \leq 0,05)$.

Normalmente, solos estressados tendem a responder mais lentamente à adição de carbono do que solos não perturbados (Wardle, 1994).

De acordo com Yeates et al. (1994), a RIS demonstra o estado fisiológico da microbiota e pode ser utilizado como um indicador de distúrbios ou estresses mais sensível do que a RB, no caso de solos pouco contaminados onde não ocorrem perdas de biomasssa.

Brohon et al. (2001), ao avaliarem a atividade microbiana em solos contaminados com hidrocarbonetos observaram RIS maior em zonas altamente poluídas do que em zonas menos poluídas.

Similar ao que foi observado neste experimento, Emmerling et al. (2000) encontraram incrementos significativos na RIS em função da aplicação de biossólidos. Os autores atribuíram este estímulo à adição de substâncias orgânicas, nutrientes e microrganismos, bem como a um aumento do $\mathrm{pH}$ do solo.

A Food and Agriculture Organization of the United Nations (FAO, 2001), define estresse como uma força de perturbação freqüente (algumas vezes contínua), relativamente pequena e predizível, com um efeito grande e cumulativo, citando como exemplos a salinidade, toxicidade, erosão, dentre outras. Alternativamente, o distúrbio pode ser causado por um impacto, que é definido como uma força infreqüente, relativamente grande e não predízivel, com um efeito imediato. Exemplos de distúrbios são a seca, inundação, uma peste, dentre outros. Após um estresse ou distúrbio, o agroecossistema pode ser: não afetado; pode sofrer um decréscimo em suas características físicas, químicas e biológicas e depois retornar para o nível anterior; pode sofrer um decréscimo em suas características físicas, químicas e biológicas e depois se estabelecer em menor nível; e pode se tornar não funcional. 


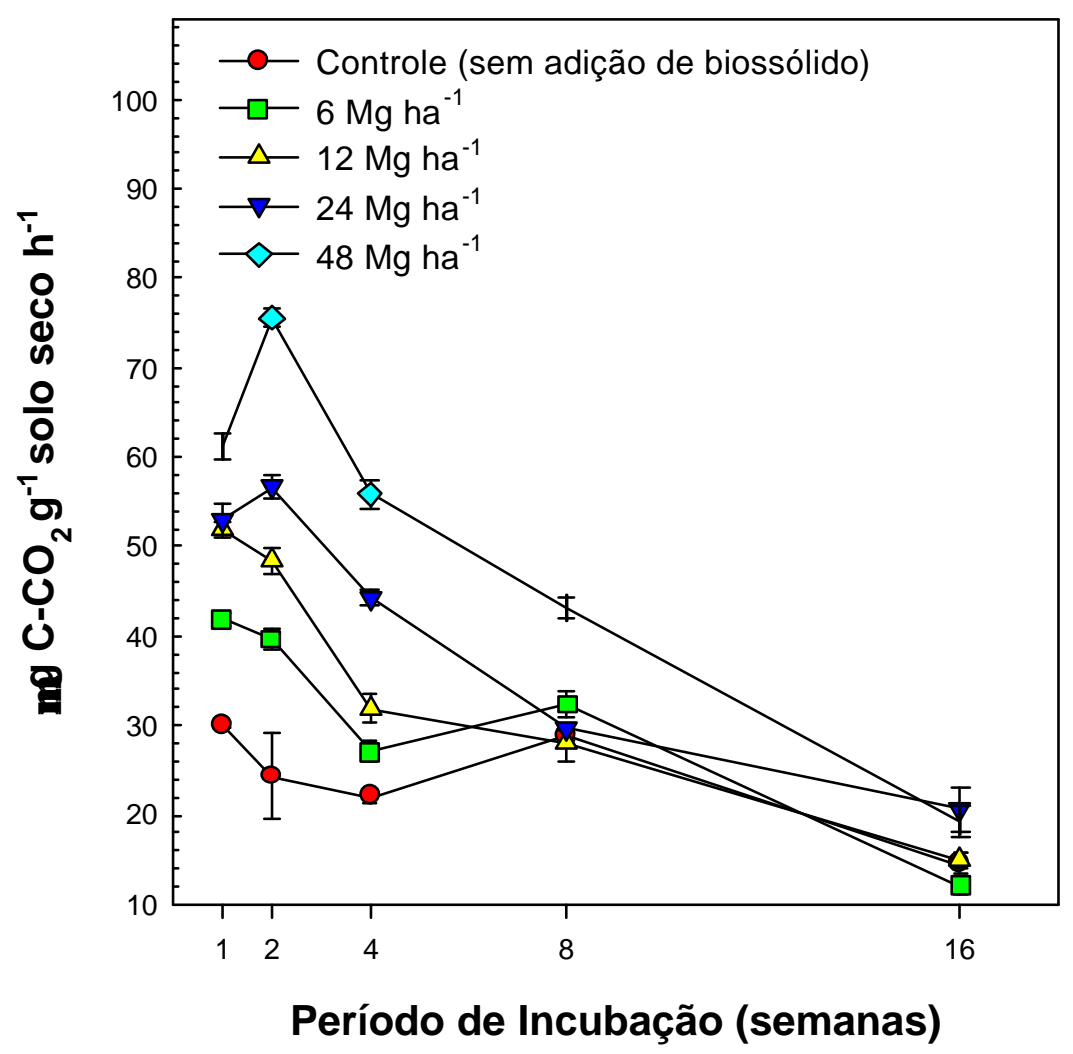

Figura 5 - Variação da Respiração Induzida pelo Substrato (RIS) em solo argiloso contendo biossólido da ETE-Franca. Os dados são médias de 4 repetições \pm desvio padrão da média. 
Em nosso estudo, os maiores valores de RB e RIS observados nos tratamentos com as maiores doses de biossólidos, mesmo no final do período de incubação, sugerem que a adição de biossólido da ETE-Franca ao solo argiloso usado no experimento causa um distúrbio das atividades microbianas, e que essas atividades tendem a se igualar à atividade microbiana do solo controle com 4-8 semanas de incubação, dependendo da dose de biossólido aplicada.

\subsection{Quociente Metabólico $\left(q \mathrm{CO}_{2}\right)$}

A variação do $q \mathrm{CO}_{2}$ pode ser observada na Figura 6. $\mathrm{O} q \mathrm{CO}_{2}$ no tratamento que recebeu o equivalente a $48 \mathrm{Mg} \mathrm{ha}^{-1}$ foi significativamente maior $(\mathrm{p} \leq 0,05)$, do que no controle sem adição de biossólido na $1^{\mathrm{a}}$ e $2^{-\mathrm{a}}$ semanas de incubação. $\mathrm{Na} 4^{\underline{a}}$ e 8모 semanas, não há diferenças significativas para nenhum tratamento, em relação ao controle. Ao final do período de incubação (16 semanas), os solos que receberam o equivalente a 12, 24 e $48 \mathrm{Mg} \mathrm{ha}^{-1}$ apresentam valores de $q \mathrm{CO}_{2}$ significativamente maiores em relação ao controle, sem biossólido. Deve-se ressaltar que, para a análise estatística, os dados foram transformados utilizando-se a raiz quadrada, para que seguissem uma distribuição normal. $\mathrm{O} q \mathrm{CO}_{2}$ tem sido utilizado como um indicador de estresse microbiano e interpretado como "eficiência microbiana", já que se trata da avaliação da energia necessária para manutenção da atividade metabólica em relação à energia necessária para síntese de biomassa (Bardgett \& Saggar, 1994). Assim, solos estressados apresentariam $q \mathrm{CO}_{2}$ mais elevado do que solos não estressados.

Fortes Neto (2000), avaliando a degradação de biossólidos em solos florestais, observou que o $q \mathrm{CO}_{2}$ aumentou proporcionalmente às doses de biossólidos adicionadas aos solos. Este índice atingiu o valor máximo 4 semanas após a adição do biossólido.

$\mathrm{O} q \mathrm{CO}_{2}$ também foi avaliado por Carmo (2000), ao estudar o impacto da aplicação de biossólidos da ETE-Franca em solo argiloso. Esta autora encontrou valores significativamente maiores do $q \mathrm{CO}_{2}$ para os solos com as doses mais elevadas de 


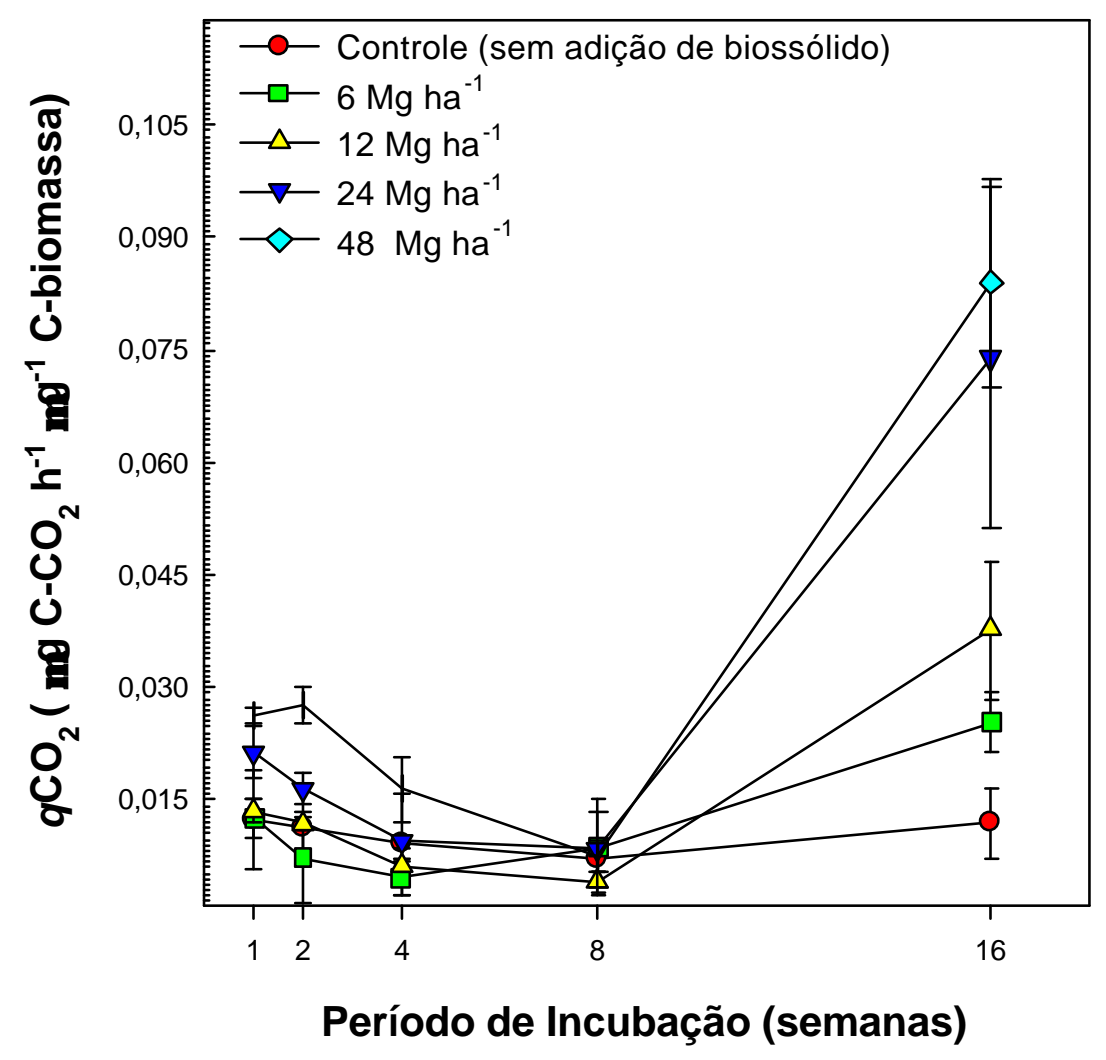

Figura 6 - Quociente Metabólico $\left(q \mathrm{CO}_{2}\right)$ em solo argiloso contendo biossólido da ETEFranca, em função do período de incubação. Os dados são médias de 4 repetições \pm desvio padrão da média. 
biossólidos logo após sua aplicação, não diferindo, entretanto, do controle, após 64 dias de incubação.

Um incremento no $q \mathrm{CO}_{2}$ também foi observado por Brookes et al. (1996) e Fließ bach e al. (1994), avaliando a rizosfera de D. cespitosa em solos contaminados com metais. Por outro lado, Insan et al. (1996), avaliando o efeito de metais pesados no $q \mathrm{CO}_{2}$ do solo, não observaram diferenças significativas entre solos contaminados e nãocontaminados com metais pesados, principalmente $\mathrm{Cu}$ e Ni. Como os solos dos experimentos de Brookes et al. (1996) e Fließbach e al. (1994) eram ecologicamente equivalentes ao de Insan et al. (1996), concluíram que outros fatores, como a textura do solo, o pH, a quantidade de matéria orgânica ou o conteúdo de nutrientes, podem ter obscurecido os efeitos dos metais pesados sobre o $q \mathrm{CO}_{2}$.

A hipótese de que estresses, principalmente causados por metais, sobre a microbiota do solo podem ser facilmente detectados por um incremento do $q \mathrm{CO}_{2}$, independentemente de outras propriedades do solo tem sido contestada (Insam et al.,1996). Outros processos, além da respiração, podem ser efetivos quando a disponibilidade de metais pesados excede o limiar de toxicidade. É possível que baixas concentrações de metais e um curto período de exposição favoreçam uma alta taxa de ciclagem da matéria orgânica e, conseqüentemente, a respiração, enquanto que altas concentrações de metais ocasionem respostas como, por exemplo, alteração na estrutura da comunidade microbiana.

Solos urbanos contaminados com metais foram estudados por Ohya et al. (1988). Avaliando a atividade e biomassa microbianas, os autores observaram que comunidades dormentes são menos sensíveis a metais pesados do que comunidades ativas, já que é a absorção de metais pesados que determina sua toxicidade. Para organismos não tolerantes a metais, a dormência pode significar sobrevivência, já que ocorre uma baixa ciclagem de carbono. Assim, uma provável explicação para os resultados obtidos por Insam et al (1996), é a ocorrência de uma alta proporção de microrganismos dormentes. 
Neste estudo, a alteração do comportamento do $q \mathrm{CO}_{2}$ nos solos que receberam as maiores concentrações de biossólidos sugere a ocorrência de alterações na estrutura da comunidade microbiana.

\subsection{Diversidade Metabólica}

\subsubsection{Metabolismo Heterotrófico Médio}

O Metabolismo Heterotrófico Médio (MHM) foi determinado através da capacidade média de utilização das 31 fontes de carbono em placa Biolog (Figura 7). Observa-se que, na $1^{\text {a }}$ e $2^{\underline{a}}$ semanas de incubação, as quantidades de biossólidos equivalentes a 12, 24 e $48 \mathrm{Mg} \mathrm{ha}^{-1}$ induzem aumentos significativos $(\mathrm{p} \leq 0,05)$ do $\mathrm{MHM}$, em relação ao controle sem adição de biossólido. Já na 4⿳⺈ ${ }^{\mathrm{a}}$ semana de incubação, apenas o tratamento com a maior quantidade de biossólido o MHM é significativamente maior do que no controle $(\mathrm{p} \leq 0,05)$. Com 8 e 16 semanas de incubação, o MHM nos solos com biossólidos não diferem estatisticamente $(\mathrm{p} \leq 0,05)$ do controle sem biossólido.

No geral, com o decorrer do período de incubação, há uma queda significativa no MHM dos solos com biossólidos e, com 8 semanas de incubação, nenhum solo com biossólidos apresenta MHM diferente do controle.

Como houve uma prévia padronização do inóculo, os maiores valores de MHM encontrados nos solos com biossólidos não podem ser atribuídos a uma maior biomassa microbiana, mas refletem, provavelmente, alterações na fisiologia da comunidade. Os dados deste experimento indicam que a adição de biossólidos a solo argiloso induz um aumento transiente na capacidade metabólica do solo. Analisando fatores que afetam a reproducibilidade e interpretação de dados sobre a utilização de substratos de carbono por comunidades microbianas, Haack et al. (1995) obtiveram resultados que confirmam a hipótese de que diferenças no MHM de amostras com a mesma densidade de inóculo reflitam diferenças na composição da comunidade. 


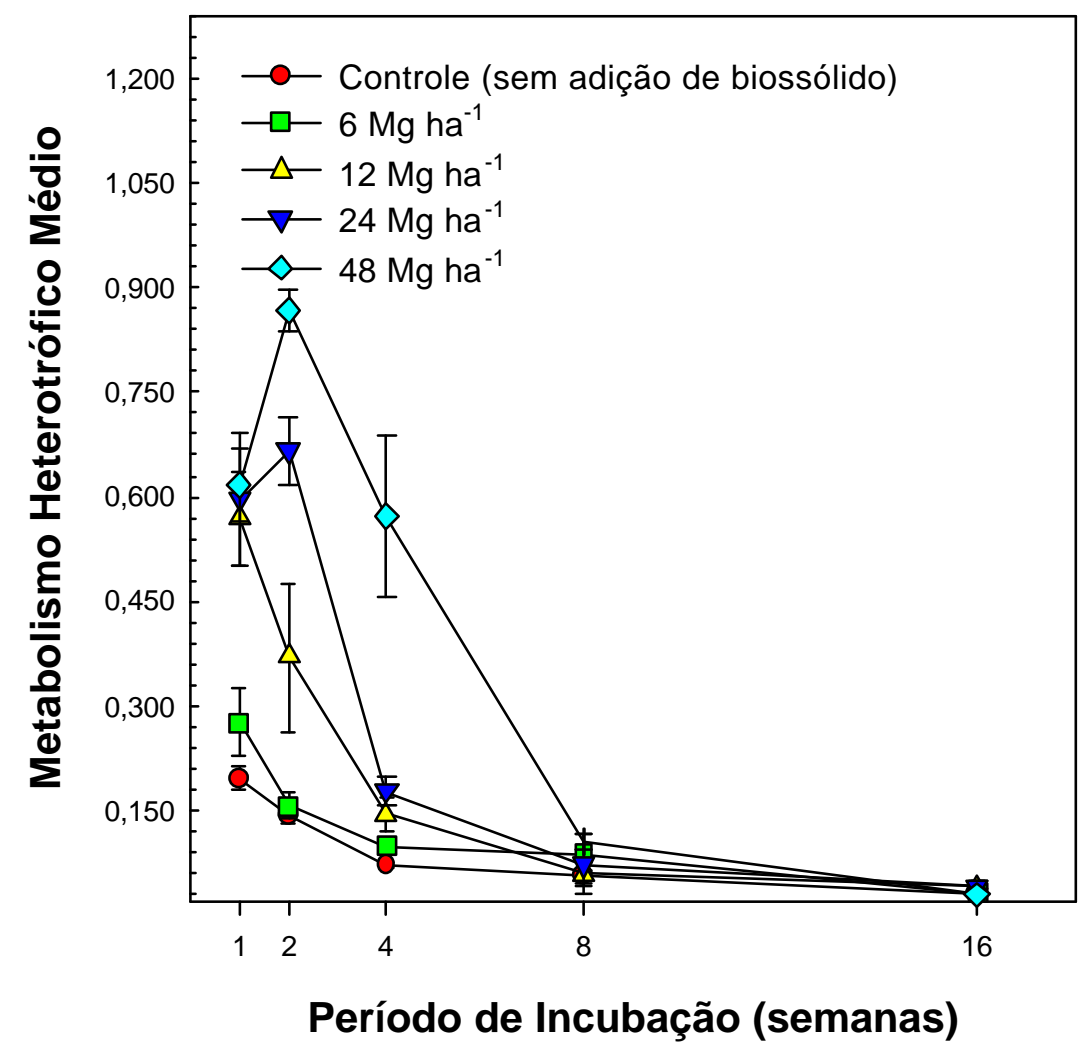

Figura 7 - Metabolismo Heterotrófico Médio (MHM) em solo argiloso contendo biossólido da ETE-Franca, em função do período de incubação. Os valores de MHM foram determinados através da absorbância média a $595 \mathrm{~nm}$, para os 31 substratos da placa Biolog. Os dados são médias de 4 repetições \pm desvio padrão da média. 
Ao contrário, Kelly et al. (1999), avaliando alterações nas comunidades microbianas do solo decorrentes da aplicação de zinco, encontraram valores significativamente menores de MHM nos solos contaminados, em relação ao controle, atribuindo, da mesma forma, estas diferenças às alterações na estrutura da comunidade microbiana.

Comparando o padrão de utilização de substratos de $\mathrm{C}$ por comunidades microbianas em sistemas de manejo convencional e orgânico, Buyer et al. (1997) encontraram valores de MHM significativamente maiores nos solos sob manejo orgânico, principalmente logo após a incorporação da palhada. Os autores atribuem este incremento a uma maior biomassa microbiana, já que não houve padronização prévia do inóculo. Entretanto, não observaram alterações na utilização de determinados substratos, indicando, provavelmente, mais uma alteração da estrutura da comunidade do que da função.

Por outro lado, Wildmer et al. (2001), comparando metodologias para avaliar as características biológicas de solos contaminados com pesticidas, encontraram diferenças significativas na capacidade de utilização de substratos de C. No entanto, estes autores ponderam que estas diferenças não podem ser totalmente atribuídas às espécies ou composição da comunidade, já que o método se baseia na fração cultivável da comunidade microbiana inoculada nas microplacas. Além disso, estes autores consideram que os microrganismos inoculados nas células das microplacas estão sujeitos à competição e, assim, somente poucas espécies contribuiriam para atividade catabólica média.

Os resultados obtidos neste trabalho indicam que a adição de biossólidos altera o metabolismo da comunidade microbiana. A variação do MHM reflete, provavelmente, uma alteração da comunidade microbiana estimulada pelo biossólido adicionado. Esta reestruturação da comunidade microbiana resultou em modificação do estado metabólico, e, conseqüentemente do MHM. 


\subsection{2 Índices de Diversidade}

A riqueza de substratos $(\mathrm{S})$, definida como o número de substratos utilizados pela comunidade microbiana nos diferentes tratamentos, ao longo do período de incubação, pode ser observada na Figura 8. Na $1^{\underline{a}}$ semana de incubação não houve diferença significativa $(\mathrm{p} \leq 0,05)$ entre os tratamentos com o biossólido e o controle. Com 2 semanas de incubação, todos os tratamentos que receberam biossólidos diferiram significativamente do controle sem adição de biossólido. Já com 4 semanas de incubação, apenas os solos que receberam as quantidades de biossólidos equivalentes à 12, 24 e $48 \mathrm{Mg} \mathrm{ha}^{-1}$ apresentaram valores de $\mathrm{S}$ significativamente maiores do que no controle sem biossólido. Com 8 e 16 semanas de incubação, o S dos solos com biossólidos não diferiram do controle sem biossólidos.

$\mathrm{O}$ Índice de Diversidade de Shannon $(\mathrm{H})$, calculado com base na capacidade de utilização de fontes de $\mathrm{C}$ nos diferentes tratamentos pode ser visto na Figura 9. $\mathrm{Na} 1^{-\mathrm{a}}$ semana de incubação, os solos que receberam o equivalente a 12, 24 e 48

$\mathrm{Mg} \mathrm{ha}^{-1}$ apresentam valores significativamente maiores de de $\mathrm{H}$, em relação ao controle sem biossólido $(\mathrm{p} \leq 0,05)$. Este comportamento se estende até a $2^{-}$semana de incubação. $\mathrm{Na} 4^{\mathrm{a}}$ - semana, apenas o tratamento que recebeu o equivalente a $48 \mathrm{Mg} \mathrm{ha}^{-1}$ apresenta valor de $\mathrm{H}$ significativamente maior que o controle, sem adição de biossólido. Com 8 e 16 semanas de incubação, o H dos solos com biossólidos igualam-se ao controle.

Esses dados indicam que a adoção de altas concentrações de biossólidos ao solo causa um aumento transiente da diversidade microbiana, a qual volta a ser estatisticamente igual ao controle sem biossólidos após 8 semanas de incubação. De uma maneira geral, a diversidade metabólica diminuiu ao longo do período de incubação, em todos os tratamentos, inclusive no controle. Esses dados sugerem que a sucessão microbiana que ocorreu no microcosmo leva a extinção das capacidades metabólicas específicas.

A equitabilidade de substratos, que avalia a uniformidade de utilização de um substrato em relação ao número de substratos utilizados pela microbiota nos diferentes tratamentos pode ser vista na Figura 10. Deve-se ressaltar que, para a análise 


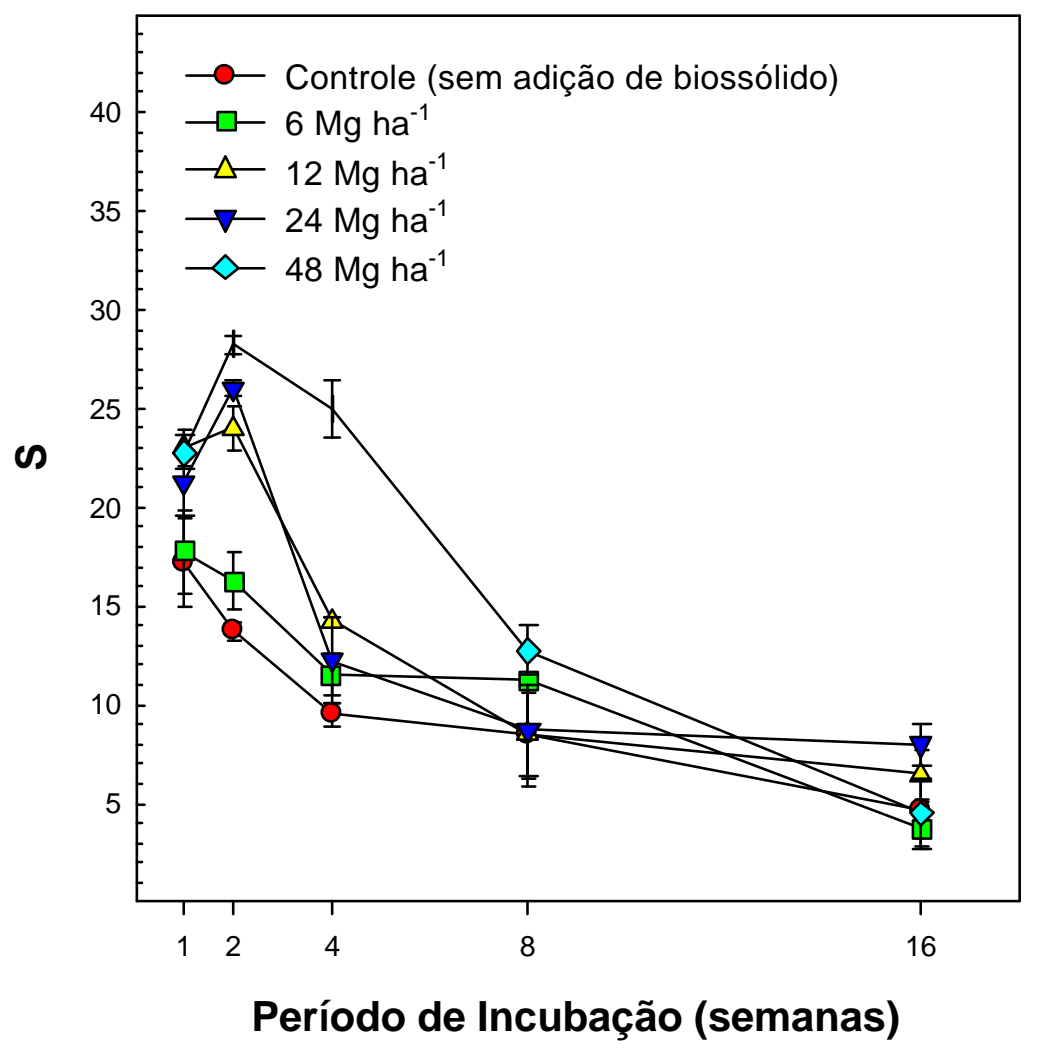

Figura 8 - Riqueza de Substratos (S) em solo argiloso contendo biossólido da ETEFranca, em função do período de incubação. Os dados são médias de 4 repetições \pm desvio padrão da média. 


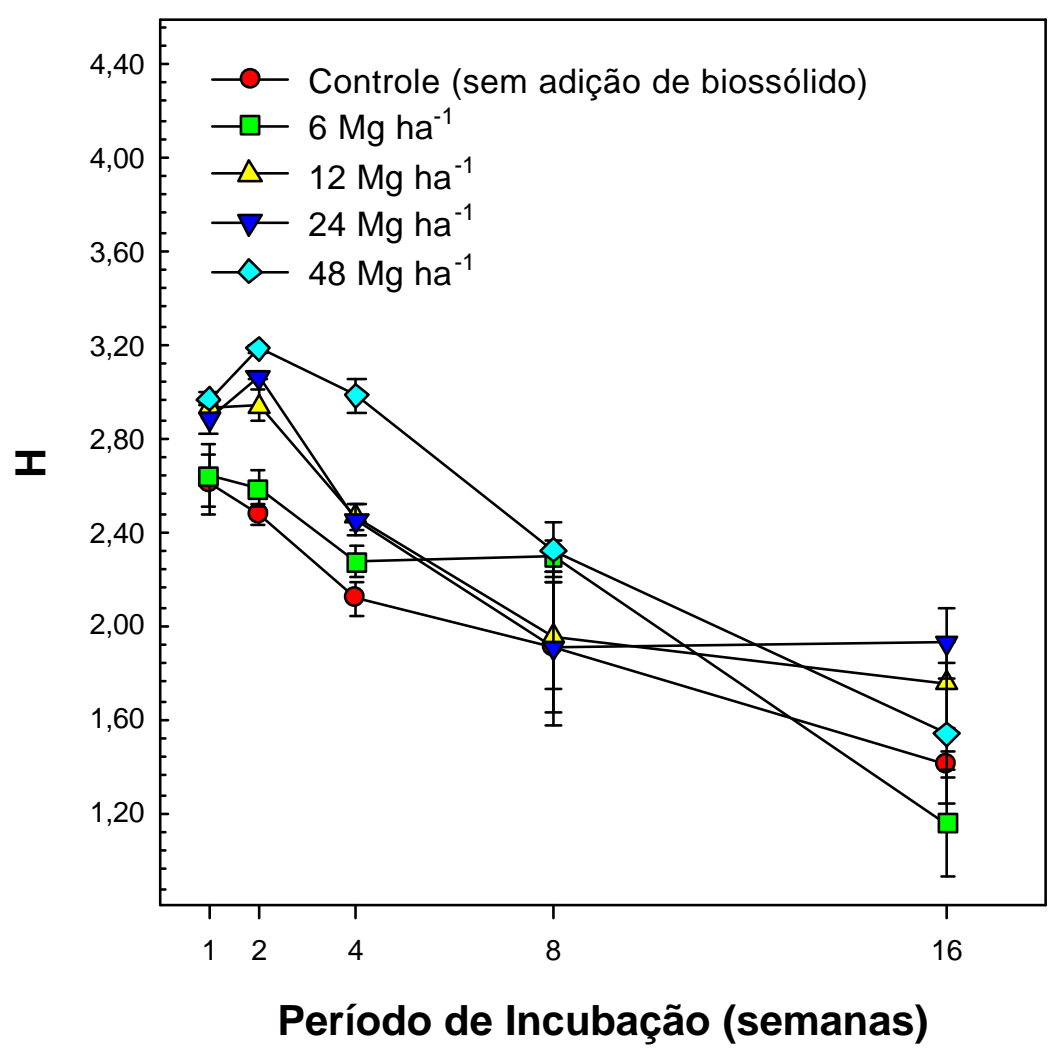

Figura 9 - Índice de Diversidade de Shannon $(\mathrm{H})$, com base na capacidade de utilização de fontes de C, em solo argiloso contendo biossólido da ETE-Franca, em função do período de incubação. Os dados são médias de 4 repetições \pm desvio padrão da média. 


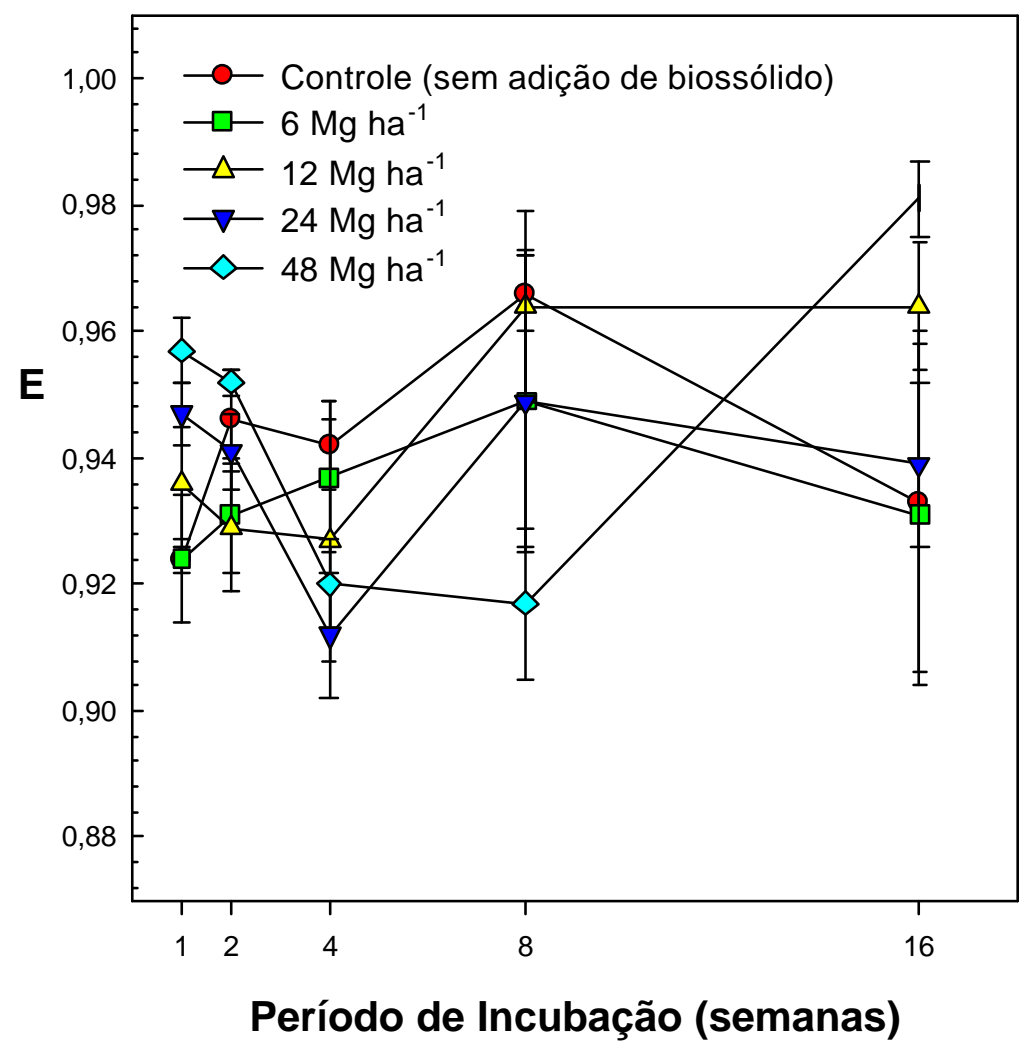

Figura 10 - Equiitabilidade de substratos (E) em solo argiloso contendo biossólido da ETE-Franca, em função do período de incubação. Os dados são médias de 4 repetições \pm desvio padrão da média. 
estatística, os dados foram transformados utilizando-se arc sen, para que seguissem uma distribuição normal. Na $1^{-}$primeira semana de incubação, apenas os tratamentos que receberam o equivalente a 24 e $48 \mathrm{Mg} \mathrm{ha}^{-1}$ apresentaram valores significativamente maiores em relação ao controle, sem adição de biossólido $(\mathrm{p} \leq 0,05)$. Nas demais épocas, não se observam diferenças significativas entre os tratamentos com biossólidos e o controle, sugerindo que a adição de biossólidos ao solo pode promover um aumento transiente nas capacidades de utilização de substratos de $\mathrm{C}$ específicos.

Comunidades microbianas diferem de outras comunidades biológicas devido ao imenso número de espécies envolvidas e, também, por seu curto período de geração. Assim, alterações nas condições ambientais responsáveis pela substituição de nichos microbianos podem favorecer a habilidade de espécies previamente dormentes em se tornar competitivas e dominar a comunidade (Yan et al., 2000).

Comparando a diversidade metabólica de sítios cultivados e não cultivados, Yan et al. (2000) encontraram valores de H significativamente menores para os sítios cultivados, em relação aos não-cultivados. Atribuíram estes resultados às maiores quantidades de C-orgânico observadas nos sítios não-cultivados, bem como aos maiores valores de $\mathrm{pH}$, sugerindo que a menor quantidade de $\mathrm{C}$-orgânico presente nos solos cultivados sejam responsáveis pela menor diversidade metabólica.

Da mesma forma, a adição de palhada de milho em solos agrícolas ocasionou incrementos significativos no $\mathrm{H}$ dos solos em relação ao solo controle, os quais persistiram prevení-los até 32 semanas após a adição da palhada. (Sharma et al.,1998).

Avaliando os efeitos de distúrbios em solos florestais, Staddon et al. (1997) verificaram que horizontes orgânicos do solo também apresentaram H significativamente maior em relação a horizontes minerais, atribuindo estas diferenças a microbiota nativa de cada solo, e ainda ao maior efeito da matéria orgânica e nutrientes dos horizontes orgânicos sobre a microbiota.

Neste estudo, os resultados sugerem que os maiores valores de $\mathrm{S}$ e $\mathrm{H}$ observados principalmente nos tratamentos que receberam as maiores quantidades de biossólido, na 1ํㅡㄹ $2^{\underline{a}}$ e $4^{\underline{a}}$ semanas de incubação, são resultantes da adição de C-orgânico 
que, além de estimular a microbiota nativa, contribuiu com novas células microbianas, incrementando os valores de $\mathrm{S}$ e $\mathrm{H}$.

\subsubsection{Perfis de Utilização de Substratos de C}

Os perfis de utilização de diferentes fontes de $\mathrm{C}$ pela microbiota dos solos com ou sem biossólidos podem ser facilmente visualizados através de uma matriz gráfica, onde a intensidade de utilização da fonte de $\mathrm{C}$ específica é representada por uma escala de cores variando de preto (não utilização) a vermelho (máxima utilização) (Figura 11). Observa-se que, tanto nos solos com biossólidos quanto no controle, houve uma diminuição na capacidade metabólica do solo devida, provavelmente, a uma alteração da comunidade microbiana ligada à depleção do carbono orgânico.

Verifica-se também que, de maneira geral, os substratos Ácido $\gamma$ hidroxibutírico (20), L-serina (27), Feniletilanina (30) e Putrescina (31), nas primeiras semanas de incubação, foram utilizados apenas nos solos que receberam as maiores quantidades de biossólido. Isto se deve, provavelmente, à uma adaptação da microbiota nativa e/ou uma mudança na composição de espécies (Baath, 1989).

Os coeficientes de similaridade dos perfis de utilização de substratos, calculados em função da ausência ou presença de atividade microbiana, podem ser vistos na Tabela 4.

$\mathrm{Na}$ primeira semana após a adição do biossólido observa-se que a quantidade correspondente a $6 \mathrm{Mg} \mathrm{ha}^{-1}$ apresenta aproximadamente $80 \%$ de similaridade em relação ao controle (sem adição de biossólido). Os demais tratamentos apresentam aproximadamente $68 \%$ de similaridade em relação ao controle. Com 2 semanas de incubação no solo com ao equivalente a $6 \mathrm{Mg} \mathrm{ha}^{-1}$ o perfil de utilização de substratos de C apresentou aproximadadmente $84 \%$ de similaridade em relação ao controle, enquanto que nos solos com as maiores doses a similaridade variou entre aproximadadmente 55 e 61\%. Com 4 semanas de incubação, as similaridades em relação ao controle aumentam, exceto para o solo com a maior dose de biossólidos ( $\sim 35 \%)$. Depois de 8 e 16 semanas 


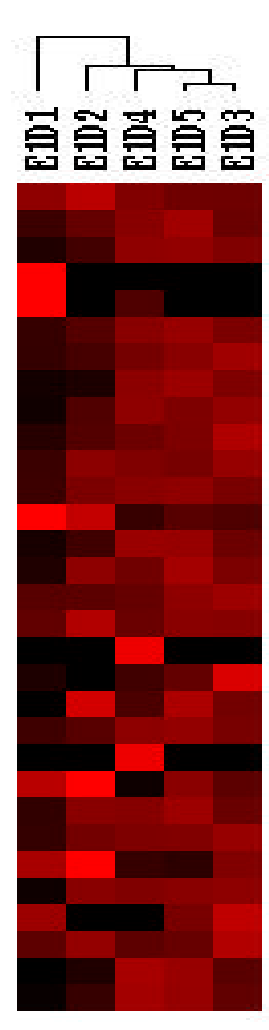

1
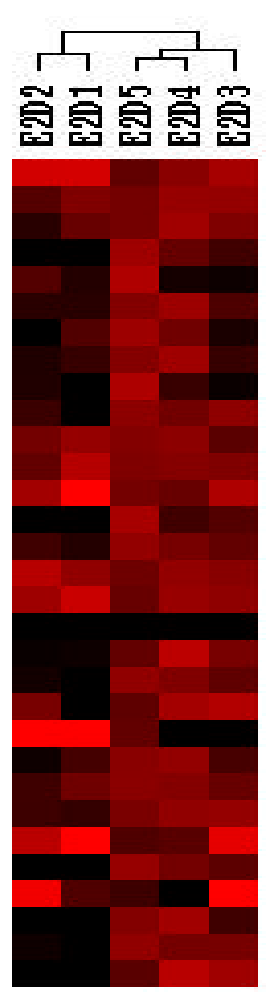

2
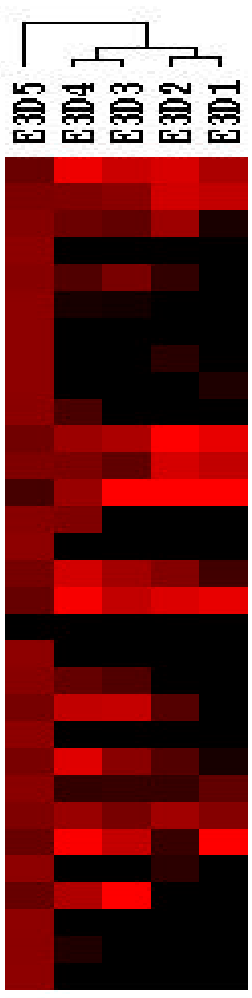

4

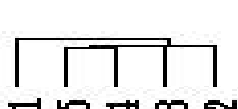

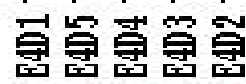

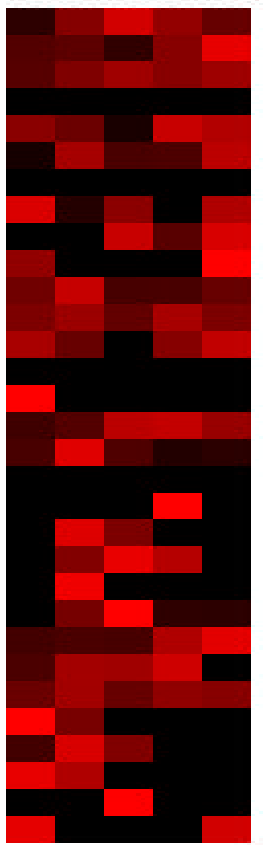

8

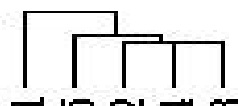

\section{돌}

Ester Methlico do Ácido Pińnico

Tween 40

Tween 80

$\alpha$ Cidodextrina

Glicogênio

D-Celobiose

$\alpha$ DLactose

$\beta$-MetitDGlicosídeo

D-Xilose

i-Erithritol

D-Manitol

$N$-Acetil-DGlicosamina

ÁcidoD-glicosamínico

Glicose-1-fosfato

$D, L-0$ Glicerol fosfato

Ácido DGalacturônico Y-Lactona

Ácido DGalacturônico

Ácido 2-Hidroxibenzóico Ácido 4Hidroxibenzóico

Ácido $\gamma$ Hidroxibuturico

Ácido Itacônico

Ácido o-Cetobutínico

Ácido DMálico

L-Arginina

L-Asparagina

L-Fenil alanina

LSSerina

L-Treonina

Ácido Glicil-Lghutâmico

Fenil etilanina

Putrescina

16

\section{Período de Incubação (semanas)}

Figura 11- Análise de agrupamento hierárquico com base na capacidade de utilização de fontes de $\mathrm{C}$ em solo argiloso contendo biossólido da ETE-Franca, em função do período de incubação. D1, controle sem biossólido; D2, D3, D4 E D5, solo com o equivalente a $6,12,24$ e $48 \mathrm{Mg}$ biossólido ha $^{-1}$, respectivamente. A coloração das células indica a capacidade de utilização de fontes de C; células pretas indicam não utilização de fonte de $\mathrm{C}$; células vermelhas indicam utilização de fonte de $\mathrm{C}$; a intensidade da cor é proporcional à intensidade de utilização de fonte de $\mathrm{C}$. 
Tabela 4. Coeficientes de similaridade em função da ausência ou presença de atividade microbiana no solo tratado com biossólido da ETE-Franca.

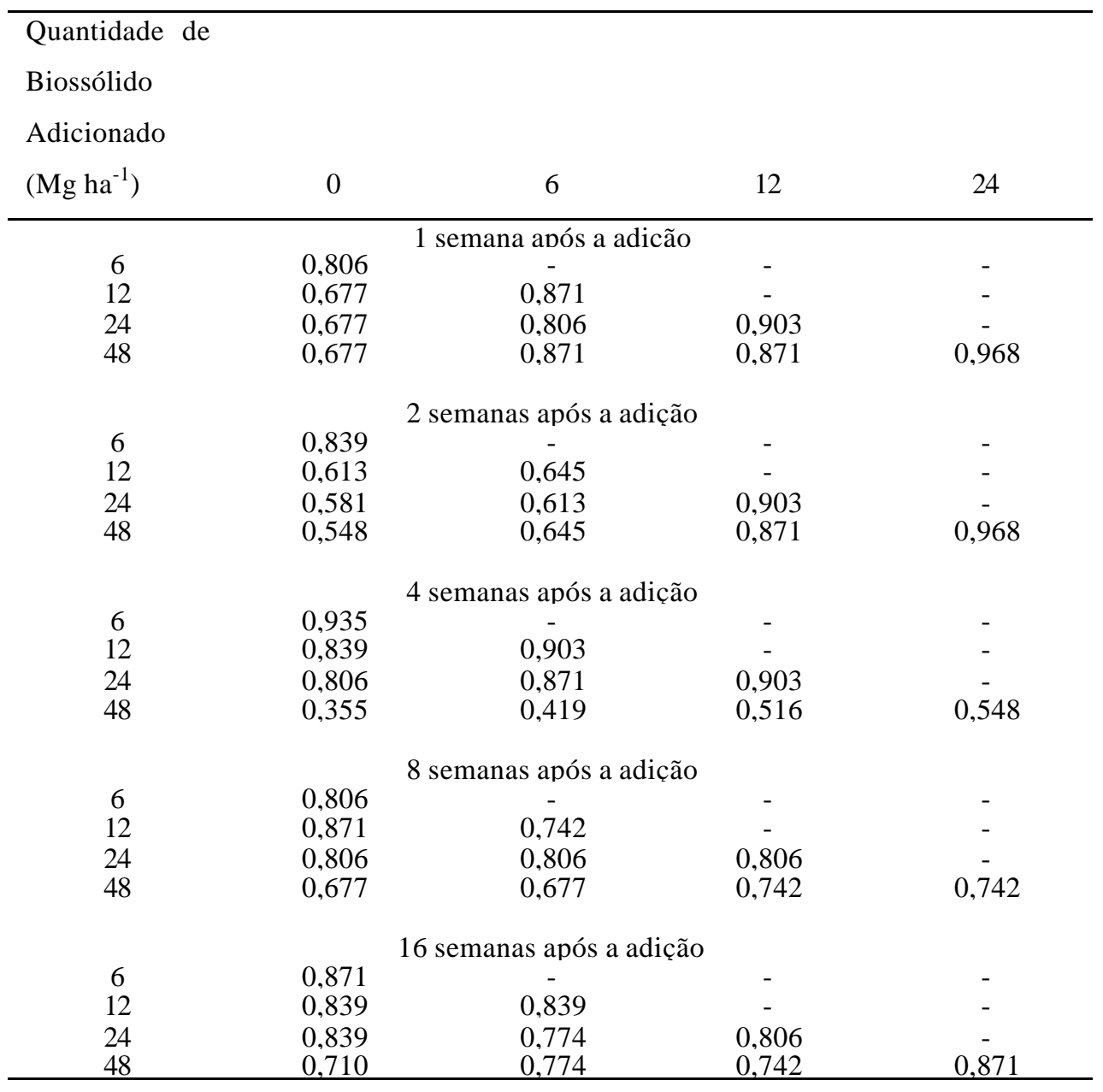


de incubação, os perfis de utilização de fontes de $\mathrm{C}$ pela microbiota dos solos com biossólidos foram mais similares aos do controle sem biossólidos do que no início do experimento.

No geral, os perfis de utlização de fontes de C pela microbiota dos solos com as maiores doses de biossólidos foram mais similares entre si do que em relação ao controle sem biossõlidos.

A similaridade dos perfis de utilização de fontes de $\mathrm{C}$ pela microbiota nos diferentes tratamentos pode ser avaliada através da análise de agrupamento hierárquico com base em matrizes de similaridade. Os dados mostram, de uma maneira geral, um aumento transiente da capacidade metabólica nos solos com biossólidos, em relação ao controle sem biossólidos, no início do período de incubação. Adicionalmente, houve uma diminuição generalizada na capacidade metabólica dos solos, com ou sem biossólidos ao longo do período de incubação. O agrupamento hierárquico revelou que no início do período de incubação, os perfis de utilização de fontes de C pela microbiota dos solos com biossólidos foram mais semelhantes entre si do que em relação ao controle sem biossólidos. Ao longo do período de incubação, os perfis de utilização de fontes de $\mathrm{C}$ nos solos com biossólidos foram se tornando mais similares aos do controle, indicando uma recuperação do distúrbio causado pela adição de biossólidos sobre a capacidade metabólica da microbiota.

No geral, os dados sugerem que a aplicação de biossólidos ao solo argiloso provoca um distúrbio na fisiologia da microbiota do solo, e que aplicações sucessivas de altas doses de biossólidos podem levar a alterações significativas na capacidade metabólica dos solos. As implicações dessas alterações para a manutenção da fertilidade do solo são desconhecidas, e deverão ser melhor estudadas.

A aplicação de biossólido aos solos pode induzir alterações significativas nos habitats microbiano. Assim, os resultados obtidos pela comparação dos perfis de utilização de substratos de C confirmam esta hipótese. A utilização de substratos pela comunidade foi substancialmente influenciada pela quantidade de biossólido adicionado, e também pelo período de incubação. 
Da mesma forma, Pennanem (2001), avaliando comunidades microbianas em florestas de coníferas expostas a metais pesados, verificou que os solos severamente poluídos com metais apresentaram perfis de utilização de fontes de $\mathrm{C}$ similares, distintos dos solos pouco ou não poluídos. Em nosso estudo, as similaridades entre os perfis de utilização de substratos $\mathrm{C}$ diminuiram com o aumento da concentração de biossólido no solo, em relação ao controle sem biossólido, e aumentaram em função do período de incubação. No geral, os dados indicam que a aplicação de biossólidos altera a diversidade metabólica do solo somente nas primeiras semanas de incubação. Após 8 semanas de incubação, os efeitos do biossólido no metabolismo da microbiota não são mais detectáveis. 


\section{CONCLUSÕES}

Com base na RB, RIS e MHM, pode-se concluir que houve uma indução transiente no metabolismo da microbiota do solo, em função da aplicação de biossólido da ETE-Franca, e que essa indução é diretamente proporcional à dose de biossólido aplicada ao solo.

A aplicação de biossólido ao solo induziu um aumento transitório da diversidade metabólica $(\mathrm{H})$, determinada pela capacidade de utilização de fontes de $\mathrm{C}$ em microplacas Biolog..

O aumento do $q$-CO2 nos solos com as maiores doses de biossólidos, no início e final do período de incubação, sugere a ocorrência de condições estressantes para a microbiota e sucessão de populações de microrganismos.

No geral, os resultados sugerem que a aplicação de biossólidos da ETEFranca no solo argiloso utilizado provoca um distúrbio na fisiologia da microbiota do solo e que aplicações sucessivas de altas doses de biossólido podem levar a alterações significativas na capacidade metabólica dos solos. 


\section{REFERÊNCIAS BIBLIOGRÁFICAS}

ANDERSON, J.P.E.; DOMSCH, K.E.; A physiological method for the quantitative measurement of microbial biomass in soils. Soil Biology and Biochemistry, v.10, p-215-221, 1978.

AOYAMA, M.; YTAYA, S. Effects of copper on the metabolism of $\mathrm{C}_{14}$ labeled glucose in soil in relation to amendment wity organic materials. Soil Science and Plant Nutrition, v.41, p. 245-252, 1995.

BAATH, E. Effects of heavy metals in soil on microbial processes and populations: a Review. Water, Air and Soil Pollution, v. 47, p. 335-379, 1989.

BAATH, E.; DÍAZ-RAVINA, M.; FROSTEGARD, A.; CAMPBELL, C.D. Effect of metal-rich sludge amendments on the soil microbial community. Applied and Environmental Microbiology, v. 64, p. 238-245, 1998.

BANERJEE, M.R.; BURTON, D.L.; DEPOE, S. Impact of sewage sludge apllication on soil biological characteristics. Agriculture, Ecosystems and Environment, v.66, p. 241-249, 1997.

BARDGETT, R. D.; SAGGAR, S. Effect of heavy metal contamination on the shortterm decomposition of labelled $\left({ }^{14} \mathrm{C}\right)$ in a pasture soil. Soil Biology and Biochemistry, v.26, p. 727-733, 1994.

BOLTON Jr., H.; FREDRICKSON, J.K.; ELLIOTT, L.F. Microbial ecology of the rhizosphere. In: METTING Jr.; BLANE, F. (Ed.). Soil microbial ecology: application in agricultural and environmental management. New York: M. Dekker, 1993. p.27-63. 
BOSSIO, D.A.; SCOW, K.M. Impact of carbon and flooding on the metabolic diversity of microbial communities in soils. Applied and Environmental Microbiology, v. 61, p.4043-4050, 1995.

BROHON, B.; DELOLME C.; GOURDON, R. Complementarity of bioassays and microbial activity measurementes for the evaluation of hydrocarbon-contaminated soils quality. Soil Biology and Biochemistry, v.33, p. 883-891, 2001.

BROOKES, P.C. The use microbial parameters in monitoring soil pollution by heavy metal. Biology and Fertility of Soils, v.19, p.269-279, 1995.

BROOKES, P.C.; McGRATH, S.P. Effects of metal toxicity on the size of the soil microbial biomass. Journal of Soil Science, v, 35, p. 341-346,1984.

BUCHANAN, M.; GLISSMAN, S. How compost fertilization affects soil nitrogen and crop yield. Biocycle, v.12, p.2-7, 1991.

BUYER, J.S.; DRINKWATER, L.R. Comparison of substrate utilization assay and fatty acid analysis of soil microbial communities. Journal of Microbiological Methods, v.30, p.3-11, 1997.

CALDEIRA, D.S.A. Cinética da degradação de compostos orgânicos no solo. Piracicaba, 1997. 68p. Dissertação (Mestrado) - Escola Superior de Agricultura "Luiz de Queiroz", Universidade de São Paulo.

CARMO, J.B. Impacto da aplicação de biossólidos nas atividades microbianas do solo. Piracicaba, 2000. 105p. Dissertação (Mestrado) - Escola Superior de Agricultura "Luiz de Queiroz", Universidade de São Paulo.

CHANDER, K.; BROOKES, P.C. Microbial biomass dynamics during the decomposition of glucose and maize in metal-contaminated and non-contaminated soils. Soil Biology and Biochemistry, v. 23, p.917-925,1991.

CHANDER, K.; BROOKES, P.C. Residual effects of zinc, copper and nickel in sewage sludge on microbial biomass in a sandy loam. Soil Biology and Biochemistry, v. 25, p.1231-1239,1993.

CHANDER, K.; BROOKES, P.C.; HARDING, S.A. Microbial biomass dynamics folloowing addition of metal-enriched sewage sludges to a sandy loam. Soil Biology and Biochemistry, v.27, p. 1409-1421, 1995. 
COMPANHIA DE TECNOLOGIA E SANEAMENTO AMBIENTAL. Aplicação de biossólidos em áreas agrícolas: critérios para projeto e operação. São Paulo, 1998. $36 \mathrm{p}$.

COMPANHIA DE SANEAMENTO BÁSICO DO ESTADO DE SÃO PAULO. Informações institucionais sobre a empresa. $\underline{\text { www.sabesp.com.br }}$ (05 set. 2001)

CONSERVATION FOUNDATION. State of the environment, a view toward the nineties. Washington, 1987.

CONSULTATIVE GROUP ON INTERNATIONAL AGRICULTURAL RESEARCH. Technical Advisory Committee to the CGIAR. Sustainable agricultural production: implications for international agricultural research; report. Washington, 1988.

DAUBER, J.; WOLTERS. V. Microbial activity and functional diversity in the mounds of three different ant especies. Soil Biology and Biochemistry, v.32, p. 93-99, 2000 .

DEGENS, B.P.; HARRIS, J.A. Development of a physiological approach to measuring the catabolic diversity of soil microbial communities. Soil Biology and Biochemistry, v. 29, p.1309-1320, 1997.

DOELMAN, P.; HAANSTRA, L. Long-term and short-term effects of cadmium, chromium and zinc on soil microbial respiration in relation to abiotic soil factors. Plant and Soil, v.79, p. 317-327, 1984.

DORAN J.W. Soil quality and sustainability. Rio de Janeiro: Comissão do "V Inventory, Genesis, Morphology and Clasification of Soils" no XXVI Congresso Brasileiro de Ciência do Solo, 1997. 19 p.

DORAN, J.W.; ZEISS, M. Soil health and sustainability: managing the biotic component of soil quality. Applied Soil and Ecology, v.15, p.3-11, 2000.

EISEN, M.B.; SPELLMAN, P.T.; BROWN, P.O.; BOTSTEIN, D. Cluster analysis and display of genome-wide expression patterns. Proceedings of the National Academy of Sciences USA, v. 95, p. 14863-14868, 1998. 
EMMERLING， C.; LIEBNER， C.; HAUBOULD-ROSAR， M.; KATZUR， J.; SCHRÖDER, D. Impact of application of organic waste materials on microbial and enzyme activities of mine soils in the Lusatian coal mining region. Plant and Soil, v.220, p. 129-138, 2000.

FAO Sustainable farming systems. www.fao.org/regional/seur/Rewiew/Sust far.htm (22 nov. 2001).

FORTES NETO, P. Degradação de biossólido incorporado ao solo avaliada através de medidas microbiológicas. Piracicaba, 2000. 113p. Tese (Doutorado) - Escola Superior de Agricultura “Luiz de Queiróz”, Universidade de São Paulo.

FLIEßBACH, A.; MARTENS, R.; REBER, H.H.. Soil microbial biomass and microbial activity in soil treated with heavy metal contaminated sewage sludge. Soil Biology and Biochemistry, v.26, p. 1201-1205, 1994.

GARLAND, J.L. Patterns of potential c source utilization by rhizospher communities. Soil Biology and Biochemistry, v.28, p. 223-230, 1996.

GARLAND, J.L; MILLS, A.L. Classification and characterization of heterotrophic microbial communities on the basis of patterns of community-level sole-carbonsource utilization. Applied Environmental and Microbiology, v.57, p. 2351-2359, 1991.

GILLER, K.E.; WITTER, E.; McGRATH, S.P. Toxicity of heavy metals to microorganisms and microbial processes in agriculture soils: a review. Soil Biology and Biochemistry, v. 30, p. 1389-1414, 1998.

GILLER, K.E.; BEARE, M.H.; LAVELlE, P.; IZAC, A.M.N; SWIFT, M.J. Agricultural intensification, soil biodiversity and agroecosystem function. Applied Soil and Ecology, v. 6, p. 3-16, 1997.

GOODFRIEND, W.L. Microbial community patterns of potential substrate utilization: a comparison of salt marsh, sand dune, and seawater-irrigated agronomic systems. Soil Biology and Biochemistry, v.30, p. 1169-1176, 1998.

HAACK, S.K.; GARCHOW, H; KLUG, M.J.; FORNEY, L.J. Analysis of Factors Affecting the accuracy, Reproducibility, and interpretation of Microbial Community 
Carbon Source utilization Patterns. Applied and Environmental Microbiology, v.61, p.1458-1468, 1995.

HAIDER, K.; MARTIN, J.P. Decomposition of specifically carbon-14 labeled benzoic and cinnamic acid derivatives in soil. Soil Science and Plant Nutrition, v.38, p. 93-100, 1992.

HATTORI, H. Influence of heavy metals on soil microbial activities. Soil Science Society of America Proceedings, v.39, p. 657-662, 1989.

HAWKSWORTH, D.L. Fungi: a neglected component of biodiversity crucial to ecosystem function and maintenance. Canadian Biodiversty, v.1, p.4-10, 1992.

HERRICK, J.E. Soil quality: an indicator of sustainable land management? Applied Soil and Ecology, v.15, p.75-83, 2000.

HILLEL, D. Out of the earth: civilization and the life of the soil. Berkeley: University of California Press, 1991. 321p.

HUE, N.V.; AMIEN, I. Aluminum detoxification with green manures. Communications in Soil Science and Plant Analysis, v.20, p.1499-1511, 1989.

IBEKWE, A.M.; KENNEDY, A.C. Phospholipid fatty acid profiles and carbon utilization patterns for analysis of microbial communitu structure unde rield and greenhhouse conditions. Fems Microbiology Ecology, v. 26, p. 151-163, 1998.

INSAM, H.; HUTCHINSON, T.C.; REBER, H.H. Effects os heavy metal stress on the metabolic quotient of the soil microflora. Soil Biology and Biochemistry, v. 28, p. 691-694, 1996.

ISLAM, K.R.; WEIL, R.R. Soil quality indicator properties in mid-Atlantic soils as influenced by conservation management. Journal of Soil and Water Conservation, v.55, p.69-78, 2000.

JAENICKE, E.C. From the ground up: exploring soil quality's contribuition to environmental health. Geenbelt: Henry A. Wallace Institute for Alternative Agriculture, 1998. 42p.

JAHNEL, M.C.; CARDOSO , E.J.B.N.; SANTOS, C.T. Determinação do número mais provável de microrganismos do solo pelo método de plaqueamento por gotas. Revista Brasileira de Ciência do Solo, v.23, p. 553-559, 1999. 
KELlY, J.J.; HAGGBLOM, M.; TATE III, R.L. Changes in soil microbial communities over time resulting from one time application of zinc: a laboratory microcosm study. Soil Biology and Biochemistry, v.31, p.1455-1465, 1999.

KENNEDY, A. C.; SMITH, K.L. Soil microbial diversity and the sustainability of agricultural soils. Plant and Soil, v.170, p. 75-86, 1995.

KHAN, M.; SCULLION, J. Microbial activity in grassland soil amended with sewage sludge containing varyng rates and combinations of $\mathrm{CU}, \mathrm{Ni}$ and $\mathrm{Zn}$. Biology Fertility of Soils, v.30, p.202-209, 1999.

KHAN, M.; SCULLION, J. Effect of soil on microbial responses to metal contamination. Environmental Pollution, v.110, p. 115-125, 2000.

LEITA, L.; DeNOBILI, M.; MUHLBACHOVA, G.; MONDINI, C.; MARCHIOL, L.; ZERBI, G. Bioavailability and effects of heavy metals on soil microbial biomass survival during laboratory incubation. Biology and Fertility of Soils, v.19, p.103108, 1995.

LUPWAYI, N.Z.; ARSHAD, M.A.; RICE, W.A.; CLAYTON, G.W. Bacterial diversity in water-stable aggregates of soils under conventional and zero tillage management. Applied Soil and Ecology, v.16, p.251-261, 2001.

LYNCH, J.M.; BRAGG, E. Microrganism and soil aggregate stability. Advances in Soil Science, v.2, p. 133-171, 1985.

MELLO, I.S. de; AZEVEDO, J.L. de. Ecologia microbiana. Jaguariúna: Embrapa, CNPMA, 1998. 488p.

OHYA, H.; FUJIWARA S.; KOMAI Y.; YAMAGUCHI, M. Microbial biomass and activity in urban soils contaminated wity $\mathrm{Zn}$ and $\mathrm{Pb}$. Biology and Fertility of Soils, v. 6, p. 9-13, 1988.

PENNANEN, T. Microbial communities in boreal coniferous forest humus exposed to heavy metals and changes in soil $\mathrm{pH}$ - a summary of the use of phospholipid fatty acids, Biolog and ${ }^{3} \mathrm{H}$-thymidine incorporation methods in fiel studies. Geoderma, v.100, p.91-126, 2001. 
RAIJ, B. van; CANTARELLA H.; QUAGGIO J.A.; FURLANI A.M.C. Recomendações de adubação e calagem. 2.ed. Campinas: IAC, 1996. 285p. (IAC. Boletim Técnico, 100).

RASMUSSEN, L.D.; SØRENSEN, S.J. Effects of mercury contamination on the culturable heterotrophic, functional and genetic diversity of the bacterial community in soil. Fems Microbiology Ecology, v. 36, p. 1-9, 2001.

REBER, H.H. Simultaneous estimates of the diversity and the degradative capability of heavy-metal-affected soil bacterial communities. Biology and Fertility of Soils, v.13, p.181-186, 1992.

SARATHCHANDRA, S.U.; GHANI, A.; YEATES, G.W.; BURCH, G.; COZ, N.R. Effect of nitrogen and phosphate fertilisers on microbial and nematode diversity in pastures soils. Soil Biology \& Biochemistry, v.33, p.953-964, 2001.

SHARMA, S.; RANGGER, A.; LUTZOW, M. von; INSAM, H. Functional diversity of soil bacterial communities increases after maize litter amendment. European Journal of Soil Biology, v.34, p. 53-60, 1998.

SOIL SCIENCE SOCIETY OF AMERICA. Glossary of soil science terms. Madison, 1997. $134 \mathrm{p}$.

STADON, W.J.; DUCHSNE, L.C.; TREVORS, J.T. Microbial diversity and community structure of postdisturbance forest soil as determined by solo-carbon-source utilization patterns. Microbial Ecology, v. 34, p.125-130, 1997.

STAMATIADIS S.; DORAN, J.W.; KETTLER, T. Field and laboratory evaluation of soil quality changes resulting from injection of liquid sewage sludge. Applied Soil and Ecology, v.12, p.263-272, 1999.

STENBERG, B. Monitoring soil quality of arable land: microbiological indicators. Soil and Plant Science, v.49, p.1-24, 1999.

TORSVIK, V.; DAAE, F.L.; SANDAA, R.A; øVEREAS, L. Novel techniques for analyzing microbial diversity in natural and perturbed environments. Journal of Biotechnology, v. 64, p. 53-62, 1998. 
VAN BEELEN, P. ; DOELMAN, P. Significance and application of microbial toxicity tests in assessing ecotoxicological risks of contaminants in soil and sediments. Chemosphere, v. 34, p. 455-499, 1997.

VANCE, E.D.; BROOKES P.C.; JENKINSON D.S. An extraction method for measuring soil microbial biomass C. Soil Biology and Biochemistry, v.19, p. 703707, 1987.

YAN, F.; SCHUBERT, S.; MENGEL, K. Soil pH increase due to biological decarboxylation of organic anions. Soil Biology and Biochemistry, v. 28, p. 617624, 1996.

YEATES, G.W.; ORCHARD, V.A.; SPEIR, T.W. HUNT, J.L.; HERMANS, M.C.C. Impact of pasture contamination by copper, chromium, arsenic timber preservative on soil biological activity. Biology and Fertility of Soils, v.18, p.200-208, 1994.

YIN, B.; CROWLEY, D.; SPAROVEK.G.; MELO, W.J. de; BORNEMAN, J. Bacterial functional redundancy along a soil reclamation gradient. Applied and Environmental Microbiology, v.66, p. 4361-4365, 2000.

WAKSMAN, S.A. Principles of soil microbiology. Baltimore: The Williams and Wilkins, $1927.897 \mathrm{p}$.

WARDLE, D. A. Metodologia para quantificação da biomassa microbiana do solo. In: HUNGRIA, M.; ARAÚJO, R.S. (Ed.). Manual de métodos empregados em estudos de microbiologia agrícola. Brasília: Embrapa, 1994. cap. 21, p.419-436.

WEF RESIDUALS MANAGEMENT COMMITTEE. Biosolids and the 503 standards. Water Environment \& Technology, v.5, n.5, p.57-62, May 1993.

WILDMER, F.; FLIEßBACH, A.; LACZKÓ, E.; SCHULZE-AURICH, J.; ZEYER, J. Assessing soil biological characteristics: a comparison of bulk soil community DNA-PLFA and biology analysis. Soil Biology \& Biochemistry, v.33, p.10291036, 2001.

WÜNSCHE, L.; BRÜGGEMANN, L.; WOLFGANG B. Determination of substrate utilization patterns of soil microbial communities: An approach to assess population changes after hydrocarbon pollution. FEMS Microbiology Ecology, v. 17, p. 295306, 1995. 
ZAK, J.C.; WILLIG, M.R.; MOORHEAD, D.L.; WILDMAN, H.G. Functional Diversity of microbial communities: a quantitative approach. Soil Biology and Biochemistry, v.26, p. 1101-1108, 1994. 